\title{
Daina Pastare
}

\section{AFERENTO REDZES CEL̦U IZPĒTE NEIRODEG̦ENERATİVU PROCESU ANALİZEI PACIENTIEM AR MULTIPLO SKLEROZI}

Promocijas darba kopsavilkums medicinas doktora zinātniskā grāda iegūšanai Specialitāte - neiroloǵija 


\section{RĪGAS STRADIN,A}

UNIVERSITĀTE

Daina Pastare

\section{AFERENTO REDZES CEḶU IZPĒTE \\ NEIRODEĢENERATĪVU \\ PROCESU ANALİZEI \\ PACIENTIEM AR \\ MULTIPLO SKLEROZI}

Promocijas darba kopsavilkums

medicīnas doktora zinātniskā grāda iegūšanai

Specialitāte - neirologija

Rīga, 2016 
Promocijas darbs izstrādāts: Paula Stradina Klīniskās universitātes slimnīcas Neirolog̣ijas un Oftalmolog̣ijas klīnikā.

Darba zinātniskie vadītāji:

Dr. med. profesors Andrejs Millers,

Rīgas Stradiņa universitātes Neirologijjas un neiroḳirurğijas katedra

Dr. med. profesore Guna Laganovska,

Rīgas Stradiṇa universitātes Oftalmolog̣ijas katedra

Oficiālie recenzenti:

Dr. med. profesore Ināra Logina,

Rīgas Stradiṇa universitāte, Latvija

Dr. med. profesors Igors Aksiks,

Latvijas Universitāte, Latvija

Dr. med. profesore Katrin Gross-Paju,

Tallinn University of Technology, Igaunija

Promocijas darba aizstāvēšana notiks 2016. gada 5. decembrī plkst.15 Rīgas

Stradiṇa universitātes Medicīnas promocijas padomes atklātā sēdē Rīgā, Dzirciema ielā 16, Hipokrāta auditorijā.

Ar promocijas darbu var iepazīties RSU bibliotēkā un RSU mājas lapā: www.rsu.lv

Promocijas padomes sekretārs:

Dr. med. asoc. profesore Angelika Krūmiṇa 


\section{SATURS}

DARBĀ LIETOTIE SAİSINĀJUMI............................................................ 5

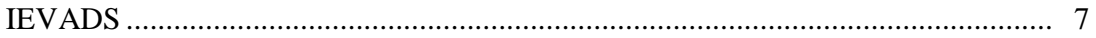

Problēmas aktualitāte ............................................................................. 7

Darba zinātniskā un praktiskā novitāte....................................................... 8

Promocijas darba struktūra un autora personīgais ieguldījums........................ 9

Ētiskie aspekti.......................................................................... 9

Darba mērķis............................................................................... 9

Darba uzdevumi............................................................................ 9

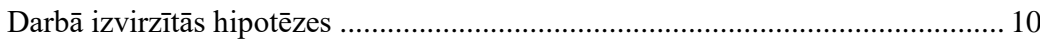

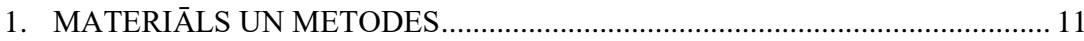

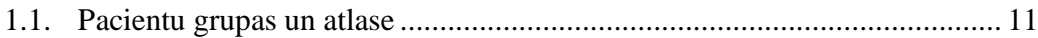

1.1.1. Iekḷaušanas kritēriji .......................................................... 12

1.1.2. Izslēgšanas kritēriji ........................................................... 12

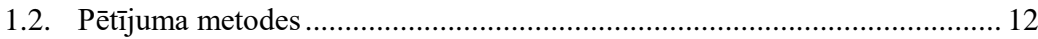

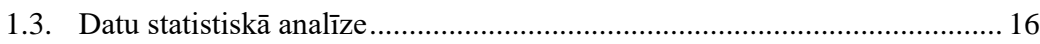

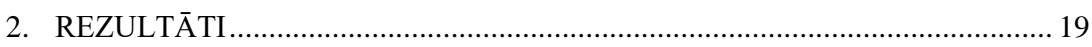

2.1. Pētījuma grupu demogrāfiskais raksturojums ....................................... 19

2.2. Slimības ilguma un pacienta neiroloǵiskā stāvokḷa raksturojums .............. 20

2.3. Funkcionālie redzes sistēmas parametri ............................................... 22

2.3.1. Redzes asums ........................................................................... 22

2.3.2. Redzes izraisītie potenciāli .................................................... 22

2.3.3. Krāsu redzes izmaiņas ............................................................... 26

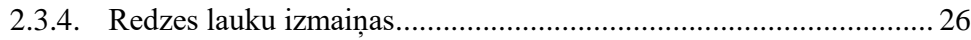

2.4. Strukturāli redzes sistēmas parametri............................................... 27

2.4.1. Redzes nerva diska nobālējums fundus oculi apskatē.................... 27

2.4.2. Tīklenes nervu šḳiedru slāṇa mērījumi ar OCT ............................ 27

2.4.3. Redzes nerva demielinizācija un demielinizējošu perēkḷu skaits magnētiskās rezonanses izmeklējumā ....................................... 30

2.5. Aferento redzes sistēmu un slimību raksturojošo rādītāju savstarpējā saistība 


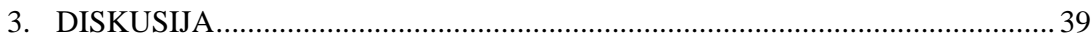

3.1. Funkcionālas aferento redzes ceḷu izmaiṇas.......................................... 39

3.2. Strukturālas aferento redzes ceḷu izmainas ............................................. 43

3.3. Turpmāko pētījumu virzieni ............................................................. 51

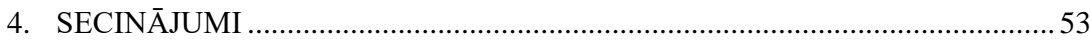

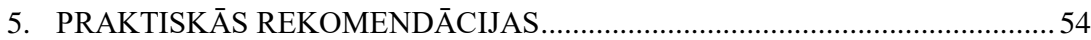

PUBLIKĀCIJAS UN ZIN̦OJUMI PAR PĒTĪJUMA TĒMU .................................. 55

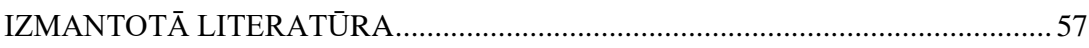

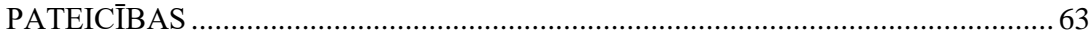




\section{DARBĀ LIETOTIE SAĪSINĀJUMI}

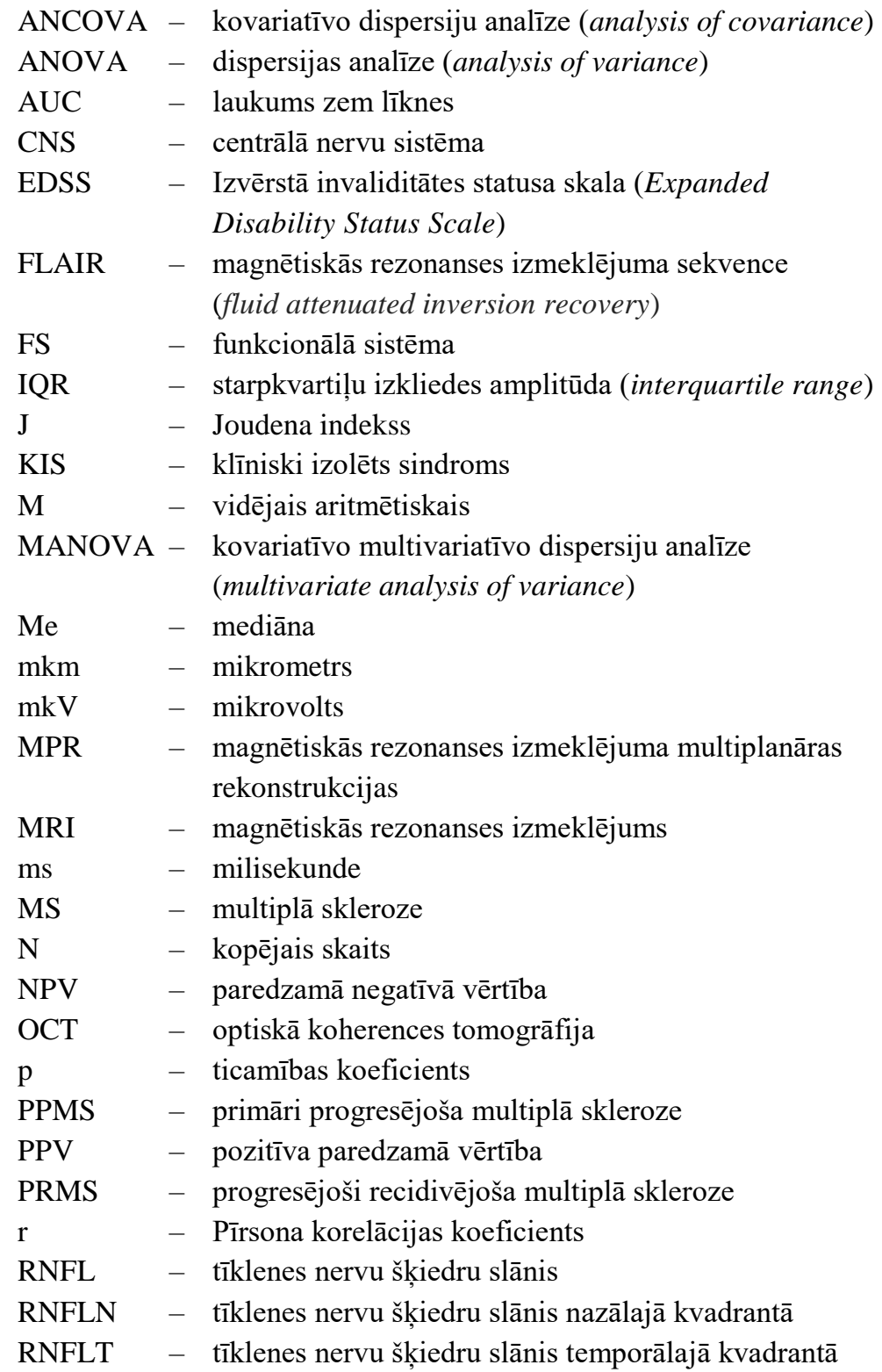




$\begin{array}{lll}\text { RNN (-) } & - & \text { acis bez redzes nerva neirīta anamnēzē } \\ \text { RNN } & - & \text { redzes nerva neirīts } \\ \text { RNN }(+) & - & \text { acis ar redzes nerva neirītu anamnēzē } \\ \text { ROC līkne } & - & \text { lēmumu pieņemšanas līkne (receiver operating } \\ & & \text { characteristic) } \\ \text { RRMS } & - & \text { recidivējoši remitējoša multiplā skleroze } \\ \mathrm{r}_{\mathrm{s}} & - & \text { Spīrmena rangu korelācijas koeficients } \\ \mathrm{SD} & - & \text { standartnovirze (standard deviation) } \\ \mathrm{Se} & - & \text { sensitivitāte } \\ \text { Sp } & - & \text { specifiskums } \\ \text { SPMS } & - & \text { sekundāri progresējoša multiplā skleroze } \\ \text { T1 } & - & \text { T1 uzsvērti attēli magnētiskās rezonanses izmeklējumā } \\ \text { T2 } & - & \text { T2 uzsvērti attēli magnētiskās rezonanses izmeklējumā } \\ \text { TI } & - & \text { ticamības intervāls } \\ \text { VEP } & - & \text { redzes izraisīitie potenciāli } \\ \varphi & - & \text { dihotomiskais koeficients }\end{array}$




\section{IEVADS}

\section{Problēmas aktualitāte}

Multiplā skleroze (MS) ir biežākais netraumatiskas invaliditātes cēlonis gados jauniem cilvēkiem, un pasaulē ir vairāk nekā 2,3 miljoni pacientu ar MS (Browne et al., 2014; WHO, 2008).

MS patoǵenēze vēl aizvien nav pilnīgi skaidra. MS ilgstoši tika uzskatîta par primāri demielinizējošu centrālās nervu sistēmas (CNS) saslimšanu, tomēr nesen pētījumos noskaidrots, ka neirodeǵeneratīviem procesiem un aksonālam bojājumam MS patoǵenēzē ir svarīgāka loma par demielinizāciju (Siffrin et al., 2010; Zipp and Aktas, 2006). Pierādīts, ka neirodeǵeneratīvs process pacientiem ar MS rodas agrīni, vēl pirms klīnisko pazīmju attīstības, un ir galvenais faktors, kas nodrošina progresējošas invaliditātes un smadzeņu atrofijas veidošanos (Bruck, 2005; Fisniku et al., 2008).

MS gaita ir l̦oti mainīga un grūti prognozējama. Vēl joprojām nav noskaidroti faktori, kas ietekmē izteikto slimības variabilitāti un pāreju no recidivējoši remitējošas uz terapijas rezistentu un progresējošu fāzi. Turklāt MS nav pilnībā izārstējama un pieejamā terapija galvenokārt balstīta uz iekaisuma procesa mazināšanu, taču maz ietekmē neirodeǵeneratīvus procesus (Fiona Costello, 2013). Pieaug nepieciešamība pēc neiroprotektīvas terapijas un biologiskiem marķieriem, ar kuru palīdzību prognozēt un monitorēt slimības gaitu, klasificēt pacientus, kā arī paredzēt un kontrolēt terapijas efektivitāti (Fernandez, 2013).

MS bieži skar redzes sistēmu. Piecpadsmit līdz divdesmit procentiem pacientu redzes traucējumi ir klīniski noteiktas MS pirmā pazīme, un gandrīz 70\% pacientu ar MS slimības laikā attīstās akūts redzes nerva neirīts (RNN) (Di Maggio et al., 2014). Aferento redzes ceḷu modelis ir piemērots klīniskais modelis MS un neiroprotektīvu medikamentu izpētei. Aferentie redzes ceḷi 
akūtas RNN epizodes gadījumā reprezentē akūtu, fokālu CNS bojājumu, bet subklīniskas, hroniskas retinopātijas un optiskas neiropātijas gadījumā ataino difūzu, hronisku CNS bojājumu.

Būtiska aferento redzes ceḷu priekšrocība ir tā, ka tie ir pieejami detalizētai un tiešai strukturālai (ar magnētiskās rezonanses izmeklējumu (MRI) un optiskās koherences tomogrāfijas (OCT) metodi) un funkcionālai izpētei (ar redzes izraisīto potenciālu (VEP) metodi, nosakot redzes asumu, krāsu redzi un redzes laukus). Šīs izmeklēšanas metodes piel̦auj dažādu, savstarpēji saistītu procesu, piemēram, iekaisuma, demielinizācijas, aksonāla bojājuma un neirodeǵenerācijas, izpēti.

Pēdējo gadu laikā veikti daudzi pētījumi par aferento redzes ceḷu izmain̄ām pacientiem ar MS, taču to rezultāti ir ļoti pretrunīgi un grūti salīdzināmi. Šajā pētījumā tika analizētas aferento redzes ceḷu pētīšanas iespējas pacientu ar MS neirodeǵeneratīvo procesu izpētei.

\section{Darba zinātniskā un praktiskā novitāte}

1. Pirmo reizi Latvijā veikts padziḷināts pētījums par aferento redzes ceḷu izmaiņām un izmeklēšanas iespējām pacientiem ar multiplo sklerozi.

2. Pirmo reizi Latvijā noteiktas precīzas redzes izraisīto potenciālu metodes rādītāju robežvērtības.

3. Pētījumā iegūti dati par iespējām diagnosticēt subklīnisku aferento redzes ceḷu bojājumu un ieteikta labākā metode tā noteikšanai.

4. Iegūti jauni dati par iespējām prognozēt strukturālu tīklenes nervu šķiedru slāņa bojājumu, izmantojot funkcionālas izmeklēšanas metodes.

5. Pētījuma rezultāti paver iespēju labāk izprast aferento redzes ceḷu strukturāli funkcionālas izmaiņas un nākotnē izmantot tās kā biologiskus marķierus pacientu ar multiplo sklerozi neirodeǵeneratīvu procesu raksturošanai. 


\section{Promocijas darba struktūra un autora personīgais ieguldījums}

Promocijas darbs uzrakstīts latviešu valodā. Promocijas darbam ir šāda struktūra: ievads, darba mērķis, uzdevumi un hipotēzes, literatūras apskats, materiāls un metodes, rezultāti, diskusija, secinājumi, izmantotās literatūras saraksts. Darba apjoms ir 119 lappuses, ieskaitot 11 tabulas, 52 attēlus un 5 pielikumus. Literatūras saraksts ietver 121 nosaukumu.

Promocijas darba autore veikusi pacientu neirologisko un neirofiziologiisko izmeklēšanu, apkopojusi, sistematizējusi un analizējusi veikto izmeklējumu rezultātus.

\section{Ẽtiskie aspekti}

Pētījuma veikšanai tika saņemta Rīgas Stradiṇa universitātes Ētikas komitejas atḷauja (1. pielikums).

\section{Darba mērķis}

Izpētīt aferento redzes ceḷu izmaiṇu nozīmīgumu multiplās sklerozes radītu neirodeǵeneratīvu procesu izvērtējumā.

\section{Darba uzdevumi}

1. Izvērtēt pacientu ar multiplo sklerozi, kam ir / nav redzes nerva neirīts anamnēzē, neirologiisko stāvokli, izmantojot Izvērsto invaliditātes statusa skalu (EDSS - Expanded Disability Status Scale).

2. Analizēt pacientu ar multiplo sklerozi, kam ir / nav redzes nerva neirīts anamnēzē, oftalmologiiskā stāvokḷa raksturojumu, nosakot redzes asumu, fundus oculi stāvokli, krāsu redzi un redzes laukus. 
3. Noteikt redzes izraisīto potenciālu metodes robežvērtības un izvērtēt P 100 latenci un N 75/P 100 amplitūdu pacientiem ar multiplo sklerozi, kam ir / nav redzes nerva neirīts anamnēzē.

4. Ar optiskās koherences tomogrāfijas metodi izpētīt tīklenes nervu šķiedru slāṇa biezumu un fokāla defekta lokalizāciju pacientiem ar multiplo sklerozi, kam ir / nav redzes nerva neirīts anamnēzē.

5. Analizēt demielinizējošu perēkḷu skaitu, izvietojumu un aktivitāti, kā arī galvas smadzeṇu atrofiju magnētiskās rezonanses izmeklējumā pacientiem ar multiplo sklerozi, kam ir / nav redzes nerva neirīts anamnēzē.

6. Statistiski analizēt iegūtos datus un noteikt klīnisko, funkcionālo un strukturālo izmainu iespējamo savstarpējo korelāciju un analizēt samazināta tīklenes nervu šķiedru slāṇa ietekmējošos faktorus.

\section{Darbā izvirzītās hipotēzes}

1.Analizējot aferentos redzes ceḷus, iespējams diagnosticēt subklīnisku multiplās sklerozes radītu neirodeǵeneratīvu procesu pacientiem bez iepriekš pārciesta redzes nerva neirīta.

2.Aferentajos redzes ceḷos konstatējamās neirodeǵeneratīvās izmaiṇas korelē ar klīniskiem, radiologiskiem un funkcionāliem rādītājiem. 


\section{MATERIĀLS UN METODES}

\subsection{Pacientu grupas un atlase}

Šḳērsgriezuma pētījumā tika iekḷauti 76 pacienti ar recidivējoši remitējošu MS, kuri tika iedalīti divās grupās:

1) pacienti ar MS un redzes nerva neirītu anamnēzē;

2) pacienti ar MS bez redzes nerva neirīta pazīmēm anamnēzē.

Pacientu ar MS grupā, kam ir redzes nerva neirīts anamnēzēe, tika atsevišķi analizētas RNN skartās acis (apzīmētas ar RNN (+)) un arī otras - RNN neskartās -acis (apzīmētas ar RNN (-)).

Kontroles grupā tika iekḷauti 28 atbilstoša vecuma un dzimuma veseli, spontāni atlasīti indivīdi. Pacienti ar MS tika piesaistîti no Paula Stradiṇa Klīniskās universitātes slimnīcas Multiplās sklerozes centra laikposmā no 2011. gada oktobra līdz 2014. gada aprīlim. Visiem pētījumā iekḷautajiem indivīdiem klīniskā neiroloǵiskā un oflalmoloǵiskā stāvokḷa izvērtěšana tika veikta P. Stradiṇa Klīniskās universitātes slimnīcas Neirolog̣ijas un Oftalmologijas klīnikā. Magnētiskās rezonanses izmeklējumi tika veikti Paula Stradiṇa Klīniskās universitātes slimnīcas Diagnostiskās radiologiijas institūtā, un izmeklējuma rezultātus interpretēja MS diagnostikā specializējies sertificēts radiologs.

Redzes nerva neirīta esamība anamnēzē tika izvērtēta, pamatojoties uz redzes nerva neirīta klīniskajām pazīmēm un simptomiem (The clinical profile of optic neuritis. Experience of the Optic Neuritis Treatment Trial. Optic Neuritis Study Group, 1991). Daļai pacientu ar MS redzes nerva neirīta epizode bija dokumentēta. Daḷa ar MS slimo pacientu turpināja sākto pirmās līnijas imūnmodulējošo (interferonu beta $1 \mathrm{a}$, interferonu beta $1 \mathrm{~b}$ vai kopaksonu) terapiju. 


\subsubsection{Iekḷaušanas kritēriji}

Pētījumā iekḷauti pacienti, kuriem:

- apstiprināta RRMS diagnoze, kas balstīta uz Makdonalda 2010. gadā izstrādātajiem kritērijiem;

- pagājuši $\geq 6$ mēneši pēc unilaterāla RNN epizodes, lai nodrošinātu laiku remielinizācijai un retrogrādai deǵenerācijai;

- pagājušas $\geq 30$ dienas pēc kortikosteroīdu terapijas, lai nodošinātu laiku medikamenta pretiekaisuma darbībai.

\subsubsection{Izslēgšanas kritēriji}

Pacienti, kuriem ir:

- akūta RNN klīniskā aina;

- $\quad$ KIS, SPMS, PPMS, PRMS diagnoze;

- refrakcijas traucējumi, kas pārsniedz \pm 6 dioptrijas;

- neirosarkoidoze, CNS limfoma, neirosifiliss, cukura diabēts u. c. saslimšanas, kuras var skart aferento redzes sistēmu;

- oftalmoloğiskas saslimšanas - glaukoma, išēmiska optiska neiropātija, redzes ceḷu trauma anamnēzē u. c.;

- nespēja piedalīties redzes sistēmas un MRI izmeklējumos.

\subsection{Pētījuma metodes}

Izmeklējumos iegūtie dati tika atzīmēti pētījuma anketās (sk. 2. pielikumu "Redzes izmeklējumu anketa" un 3. pielikumu "Magnētiskās rezonanses izmeklējuma anketa").

Multiplās sklerozes diagnoze tika noteikta, balstoties uz Makdonalda 2010. gadā izstrādātajiem kritērijiem (Chris H. Polman et al., 2011). 
Lai izvērtētu pacienta ar MS neirologisko stāvokli, tika lietota vienota klīniskās izmeklēšanas sistēma. Pacienta ar MS standartizētai, kvantitētai neirologiiskajai izmeklēšanai izmantoja Kurtckes funkcionālo sistēmu (FS) un Izvērstās invaliditātes statusa skalas (Expanded Disability Status Scale EDSS) kopvērtējumu (sk. 4. pielikumu "Izvērstā invaliditātes statusa skala" (EDSS) un 5. pielikumu "EDSS izvērtējuma veidlapa") (Kurtzke, 1983). Lai iegūtu EDSS kopvērtējuma skaitli, izmeklējumi tika veikti redzes, smadzeṇu stumbra, piramidālajāe, smadzenīšu, jušanas, zarnu un urīnpūšḷa, kā arī augstākās nervu darbības funcionālajās sistēmās. EDSS kopvērtējums no 0 līdz 3,5 ir balstīts uz detalizētu FS neiroloǵisko izmeklēšanu, savukārt, sākot no 4, balstīts uz pārvietošanās spēju vērtējumu.

Piecdesmit pacientiem ar MS tika veikts MRI izmeklējums galvas smadzenēm ar 1,5 T magnētiskā lauka stipruma MRI aparātu SIEMENS MAGNETOM AVANTO 1.5 T. Tika veikti MRI izmeklējumi FLAIR sekvencē (fluid attenuated inversion recovery) 3D ar multiplanārām rekonstrukcijām (MPR) aksiāli un / vai sagitāli, koronāli, T1 uzsvērtos attēlos 3D (T1 3D IR) ar MPR rekonstrukcijām aksiāli un / vai sagitāli, koronāli. Pacientiem ar MS tika intravenozi ievadīta kontrastviela $-0,5 \mathrm{mmol} / \mathrm{ml}$ aktīvās vielas $0,2 \mathrm{ml} / \mathrm{kg}$. Pēc kontrastvielas ievades tika nogaidītas 10 minūtes, lai tiktu vizualizēts aktīvs, kontrastvielu krājošs perēklis. Tika veikti izmeklējumi T2 uzsvērtos attēlos aksiāli 4 mm un T2 uzsvērtos attēlos FS (fat supressed) redzes nerviem koronāli $3 \mathrm{~mm}$, ietverot chiasma opticum. Vērtējot MRI rezultātus, tika analizēts demielinizējošu perēkḷu skaits, lokalizācija, aktīvu, kontrastvielu krājošu perēkḷu un galvas smadzeṇu atrofijas esamība. Iegūtie rezultāti tika atzīmēti pētījuma anketā (sk. 3. pielikumu "Magnētiskās rezonanses izmeklējuma anketa"). 
Klīniski izvērtējot oftalmolğisko stāvokli, visiem pētījuma dalībniekiem atsevišķi katrai acij tika veikti šādi redzes izmeklējumi.

1. Redzes asuma noteikšana ar redzes asuma testa burtiem, izmantojot Snelena tabulu, kas novietota 6 metru (20 pēdu) attālumā no pacienta sejas. Redzes asuma mērījumu rezultāts izteikts ar decimālskaitli, fiksējot pēdējo mazāko burtu līniju, kurā pacients spēj nosaukt vismaz trīs burtus bez kḷūdām. Redzes asums pārbaudīts katrai acij atsevišşi, otru aci aizklājot. Tika noteikta refrakcija ar koriǵējošo lēcu palīdzību. Pētījumā veiktajos aprēḳinos izmantots koriḡêtais redzes asums, turklāt gadījumos, kad redzes asums bija $\geq 1$, tas tika uzskatīts par līdzvērtīgu redzes asumam 1.

2. Intraokulārais spiediens tika mērīts ar bezkontakta tonometriju, izmantojot TONOREF II NIDEX aparātu. Par normālu acs spiedienu tika uzskatīts spiediens no 10 līdz $21 \mathrm{mmHg}$.

3. Acs priekšējo daḷu un stiklveida ķermeṇa priekšējās daḷas izmeklēšana tika veikta, izmantojot spraugas lampas biomikroskopu. Fundus oculi apskate tika veikta ar 90 dioptriju lēcām. Fundus oculi apskatē tika izvērtēta redzes nerva diska krāsa, robežas, līmenis un diagnosticēts temporāls redzes nerva diska nobālējums (ir / nav).

4. Datorizētā redzes lauku perimetrija veikta, izmantojot aparātu Oculus Centerfield Perimeter un lietojot atbilstošu redzes korekciju. Pēc redzes lauku izmeklējumiem iegūta informāciju par dažādas intensitātes gaismas punktiem, kas izkliedēti redzes laukos. Izmantota taisna leṇķa (30-2) sliekšņa programma, tīklenes jutība mērīta 54 punktos. Testētie punkti atradās $36^{\circ}$, izkliedēti no vertikālā vai horizontālā meridiāna centrālajā redzes laukā. Dažādas intensitātes gaismas stimuli tika rādīti 200 milisekundes, un pacients, identificējot gaismas stimulu, tika lūgts nospiest pogu. Perimetrisks slieksnis, kurā pacients identificē stimulu, centrāli fiksējot skatu, tika analizēts, izmantojot decibela $(\mathrm{dB})$ skalu. Gaismas intensitāte tika mērīta $\mathrm{dB}$, un zems dB lielums norāda uz lielāku izmantoto gaismas intensitāti un zemāku tīklenes jutību. 
References vērtība šai decibela skalai noteikta, ņemot vērā perimetra maksimālo stimulu spilgtumu.

5. Krāsu redzes pārbaudei tika izmantots Ishihara tests, pacientam dienas gaismā no 1 metra attāluma 5 sekundes rādot 8 polihromatiskus attēlus ar slēptiem cipariem un figūrām. Ja nepieciešams, tika veikta redzes korekcija. Pacientiem, kuri nespēja atšķirt slēptos ciparus vai figūras, tika diagnosticēti krāsu redzes traucējumi.

6. Visiem pētījuma dalībniekiem tika veikts reversējošs (pattern reversal) VEP pieraksts, izmantojot aparatūru RETI port 21 ROLAND CONSULT. Indivīdi atradās $70 \mathrm{~cm}$ attālumā no ekrāna, fiksējot skatu uz sarkanu punktu ekrāna centrā. Pieraksts tika veikts istabas $\left(20-22^{\circ} \mathrm{C}\right)$ temperatūrā. Nepieciešamības gadījumā tika veikta pilna refrakcijas korekcija. Potenciāla ieguvei tika atkārtoti monokulāri stimulēta redze ar melni baltu "šaha lauciṇa" video monitoru $1,6 \mathrm{~Hz}$ frekvencē. Potenciālu pieraksts tika veikts ar diskveida elektrodiem, tos novietojot uz pacientu galvas atbilstoši starptautiskajai 10-20 sistēmai, kas ir balstīta uz galvas izmēra mērījumiem (Odom et al., 2010). Oz ir aktīvs elektrods, kurš tika novietots uz viduslīnijas pakauša rajonā, $10 \%$ attālumā no kopējā attāluma starp deguna un pieres kaulu savienošanās vietu (nasion) un ārējo pakauša kaula izvirzījumu (inion). Parasti Oz novietošanas attālums ir 3-4 cm virs ārējā pakauša kaula izvirzījuma, kas ir tuvākais rajons galvas smadzeṇu primārai redzes garozai (17. Brodmana lauks). References diskveida elektrods tika novietots Fz rajonā. Atkārtoti veicot pa 100 stimulācijām divas reizes katrai acij, tika filtrēti un analizēti vidējie darbības potenciāli. Darbības potenciāla pirmais negatīvais vilnis tika apzīmēts ar N 75, un līknes pirmais pozitīvais vilnis tika apzīmēts ar P 100, otrais negatīvais vilnis tika apzīmēts ar N 135, un šie viļ̣ni tika pierakstīti no Oz elektroda. Līdz šim literatūrā nav precīzi definētas neirālās struktūras, kurās notiek šo VEP viḷnu veidošanās. Uzskata, ka vilnis N 75 veidojas primārajā redzes garozā, vilnis P 100 veidojas dorsālajā ekstrastriālajā okcipitālās garozas daḷā, savukārt vilnis N 135 veidojas, izplatoties impulsam 
dziḷāk smadzeṇu struktūrās, pat līdz parietālajai daivai (Slotnick, Klein, Carney, Sutter, and Dastmalchi, 1999). Laika periods no stimula līdz P 100 viļ̣na sākumam tika nosaukts par P 100 latenci un tika mērīts milisekundēs (ms). No N 75 maksimālā negatīvā punkta līdz P 100 maksimālajam pozitīvajam punktam tika veikti N 75/P 100 amplitūdas mērījumi mikrovoltos (mkV).

7. Ar optiskās koherences tomogrāfijas (OCT) metodi (Heidelberg Engineering SPECTRALIS) tika mērīts tīklenes nervu šḳiedru slāṇa (RNFL) biezums sešos standarta sektoros (temporālajā, temporālajā augšējā, temporālajā apakšējā, nazālajā, nazālajā augšèjā un nazālajā apakšējā), mērījumi izteikti mikrometros (mkm). Analizējot RNFL mērījumus, temporālā augšējā un nazālā augšêjā sektora mērījumi tika apvienoti un nodēvēti par augšējo kvadrantu, savukārt temporālā apakšējā un nazālā apakšējā sektora mērījumi tika apvienoti un nodēvēti par apakšējo kvadrantu. Visiem pētījuma dalībniekiem tika izmantota aktīva Tru Track acs izsekošanas tehnolog̣ija, kas novērš artefaktu veidošanos acu kustību dēl, RNFL biezuma rezultāti tika izvērtēti, balstoties uz OCT aparāta normatīvo datubāzi, kurā zaḷā krāsā atzīmēti rajoni tika klasificēti kā norma, bet sarkanā krāsā atzīmētie rajoni tika uzskatīti par patoloǵiski samazinātiem. Neapmierinošas kvalitātes OCT attēli tika noraidīti.

\subsection{Datu statistiskā analīze}

Datu statistiskā apstrāde tika veikta ar SPSS programmu (IBM SPSS Statistics Version 21, SPSS inc., ASV).

Kvantitatīvie main̄̄gie tika aprakstīti ar vidējo aritmētisko un standartnovirzi (SD). Gadījumos, kad sadalījums krasi atškīrās no normālsadalījuma, tika aprēķināta mediāna un starpkvartiḷu izkliedes amplitūda.

Kategoriskie jeb kvalitatīvie mainīgie tika raksturoti kā skaits un procentuāla proporcija. 
Normāli sadalīto kvantitatīvo mainīgo salīdzinājumi tika veikti ar neatkarīgo izlašu t-testu divām grupām vai ANOVA (Analysis of variance) metodi trīs un vairāk grupām. Daudzfaktoru analīzei ar papildus atfilltrējamiem parametriem tika izmantota ANCOVA (Analysis of covariance) analīze. Vienlaikus saistītu pazīmju analīzei tika izmantota multivariatīvā dispersiju analīze MANOVA (Multivariate analysis of variance).

Gadījumos, kad pētāmā pazīme neatbilda normālsadalījumam, tika izmantots atbilstošs neparametriskais Manna-Vitnija tests (Mann-Whitney U test).

Atbilstoši nosacījumiem divu pazīmju saistības analīzei tika izmantota Pīrsona (Pearson) korelāciju analīze (apzīmē ar r). Pêtījumā pieņemta šāda korelācijas ciešuma klasifikācija atkarībā no korelācijas koeficienta r lieluma: korelācija ir vāja, ja $\mathrm{r} \leq 0,30$; korelācija ir vidēja, kad $0,30<\mathrm{r}<0,70$, bet cieša, ja $\mathrm{r} \geq 0,70$. Gadījumos, kad divu pazīmju sadalījums neatbilda normālsadalījumam, tika izmantota Spīrmena (Spearmen) korelācijas koeficienta analīze (apzīmē ar $\mathrm{r}_{\mathrm{s}}$ ).

Kategoriskie jeb kvalitatīvie main̄̄gie tika salīdzināti ar Pīrsona $\chi^{2}$ (Pearson chi square) testu vai Fišera (Fisher) eksakto testu atbilstoši šo testu lietošanas nosacījumiem. Aprēķinātā Krāmera V (Cramer's V) vai dihotomiskā koeficienta (apzīmē ar $\varphi$ ) vērtība tika izmantota kvalitatīvo pazīmju analīzes statistiskā efekta novērtēšanā. Statistiskā efekta novērtēšanā tika izmantots šāds iedalījums:

- $0,1-0,3=$ mazs;

- $0,3-0,5=$ vidējs;

- $>0,5=$ liels.

Divu salīdzināmo grupu robežvērtības novērtēšanai tika izmantota ROC (Receiver Operating Characteristic) līknes analīze, aprēķinot sensitivitāti (Se), specifiskumu (Sp), maksimālo Joudena indeksu (J), pozitīvās un negatīvās 
paredzamās vērtības (PPV un NPV). Lai novērtētu statistiskā efekta lielumu, ROC līknēm tika aprēķināts laukums zem līknes (AUC - Area under curve). Tika izmantots šãds efekta lieluma iedalījums:

- $0,90-1=$ izcils;

- $0,80-0,90=$ labs;

- $0,70-0,80=$ vidējs;

- $\quad 0,60-0,70=$ vājš;

- $0,50-0,60=$ nav.

Atbilstoši vispārpieṇemtiem principiem $p$ vērtība $<0,05$ tiks uzskatīta par divpusējo testu rezultātu statistiskās ticamības slieksni. Apzīmējums n. s. - non significant tika lietots, lai norādītu p vērtības lielumu $>0,05$.

Lai iegūtos rezultātus varētu novērtēt, tika aprēḳinātas statistisko parametru 95\% ticamības intervāla (TI) robežas. 


\section{REZULTĀTI}

\subsection{Pētījuma grupu demogrāfiskais raksturojums}

Pētījumā tika iekḷauti 76 pacienti ar multiplo sklerozi, kuru vidējais vecums bija 38,64 gadi $(S D=10,60)$, minimālais vecums -17 gadi, maksimālais vecums - 65 gadi. Kontroles grupā tika iekḷauti 28 veseli indivīdi no 19 līdz 65 gadu vecumam, un šajā grupā vidējais vecums bija 35,78 gadi $(\mathrm{SD}=12,14)$.

Analizējot pētījumā iekḷauto indivīdu vidējo vecumu, balstoties uz neatkarīgo izlašu t testu, secināts, ka kontroles grupai un pacientiem vidējais vecums atšķiras par 2,58 gadiem, taču šī atšķirība nav statistiski ticama $(p=0,1)$.

Ar multiplo sklerozi slimie pacienti tika iedalīti divās grupās: pacienti ar RNN anamnēzē un pacienti bez RNN anamnēzē. Grupā ar RNN anamnēzē tika iekḷauti 33 pacienti. Grupā bez RNN anamnēzē tika iekḷauti 43 pacienti. Katram pētījuma un kontroles grupas indivīdam visi izmeklējumi tika veikti katrai acij atsevišķi. Izmeklēto acu skaits un pacientu procentuālais iedalījums kontroles un ar MS slimo pacientu grupā ar / bez RNN anamnēzē atspoguḷots 2.1. attēlā.

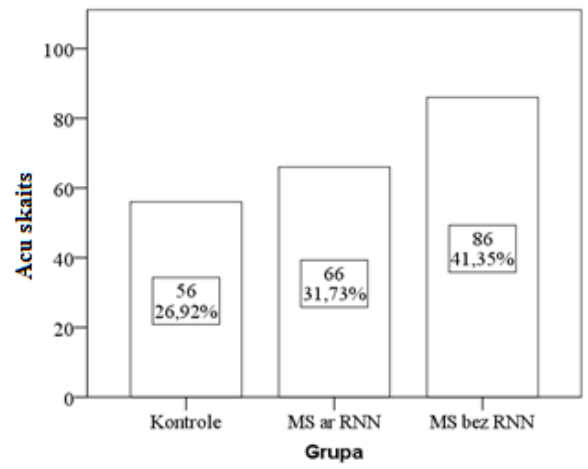

\section{1. attēls. Izmeklēto acu skaits un pacientu procentuālais iedalījums} pētījuma grupās

MS ar RNN - multiplās sklerozes pacienti ar redzes nerva neirītu anamnēzē MS bez RNN - multiplās sklerozes pacienti bez redzes nerva neirīta anamnēzē

N̦emot vērā indivīda vecuma ietekmi uz izmaiṇām aferentajā redzes sistēmā, bija būtiski noskaidrot pêtījuma grupu vecuma iedalījumu. Balstoties uz 
dispersiju analīzi (ANOVA), secināts, ka pētījumā analizētās trīs grupas pēc vidējā vecuma statistiski ticami neatšķiras $(p=0,12)$.

Kopumā ar MS slimo pacientu grupās tika iekḷautas 45 sievietes un 31 vīrietis. Kontroles grupā tika iekḷautas 19 sievietes un 9 vīrieši. Pētījuma grupu dzimuma, vecuma un izmeklēto acu skaita apkopojums sniegts 2.1. tabulā.

2.1. tabula

\section{Pētijuma grupu demogrāfiskais raksturojums}

\begin{tabular}{llcccc} 
Dzimums & \multicolumn{1}{c}{ Grupa } & N, acis $\begin{array}{c}\text { Vidējais } \\
\text { vecums, gadi }\end{array}$ & SD & $\begin{array}{c}\text { Minimālais- } \\
\text { maksimālais } \\
\text { vecums, gadi }\end{array}$ \\
\hline Sieviete & \multicolumn{1}{c}{ Kontroles } & 38 & 36,68 & 13,16 & $19,0-65,0$ \\
& MS ar RNN & 38 & 37,57 & 12,04 & $19,0-59,0$ \\
\cline { 2 - 6 } & MS bez RNN & 52 & 40,00 & 9,81 & $25,0-55,0$ \\
\hline Vīrietis & Kontroles & 18 & 33,88 & 9,70 & $25,0-57,0$ \\
\cline { 2 - 6 } & MS ar RNN & 28 & 37,21 & 7,36 & $22,0-50,0$ \\
\cline { 2 - 6 } & MS bez RNN & 34 & 38,94 & 12,31 & $17,0-65,0$ \\
\hline
\end{tabular}

MS ar RNN - multiplās sklerozes pacienti ar redzes nerva neirītu anamnēzē; MS bez RNN - multiplās sklerozes pacienti bez redzes nerva neirīta anamnēzē; $N$ - kopējais skaits; SD - standartnovirze (standard deviation)

\subsection{Slimības ilguma un pacienta neirologiiskā stāvokḷa raksturojums}

Ar MS slimu pacientu grupā ar iepriekš pārciestu RNN anamnestiski vidējais slimības ilgums bija $\mathrm{M}=39,56$ mēneši (no 6 līdz 384 mēnešiem), bet ar MS slimu pacientu grupā bez RNN anamnēzē vidējais slimības ilgums bija $\mathrm{M}=72,03$ mēneši (no 0 līdz 400 mēnešiem). Balstoties uz neatkarīgo izlašu t-testu, secināts, ka vidējais slimības ilgums ar MS slimu pacientu grupām statistiski ticami atšķiras $(\mathrm{p}=0,038)$.

Ar MS slimu pacientu grupā ar pārciestu RNN, aprēḳinot laika periodu pēc RNN epizodes, tas neatbilda normālsadalījumam, tāpēc šì perioda 
raksturošanai izmantoja mediānu un starpkvartịlı izkliedes amplitūdu $(\mathrm{Me}=12$; $\mathrm{IQR}=6$ ).

EDSS kopvērtējuma skaitlis neatbilda normālsadalījumam, un ar MS slimo pacientu grupā ar RNN anamnēzē un EDSS kopvērtējumu raksturojošais rādītājs Me ir 1,50 (IQR = 1,00), bet ar MS slimo pacientu grupā bez RNN anamnēzē EDSS Me bija 1,50 (IQR = 2). Abās pacientu grupās modālais EDSS kopvērtējuma skaitlis bija 1,50 un maksimālais EDSS kopvērtējuma skaitlis bija 6. Secināts, ka vidējie EDSS kopvērtējuma rangi abām pacientu grupām statistiski ticami neatšķiras (Manna-Vitnija tests, $\mathrm{p}=0,40$ ).

Abām pacientu grupām tika atsevišķi analizēti EDSS kopvērtējuma skaitli veidojošie funkcionālo sistēmu rādītāji. Vidējie EDSS kopvērtējuma skaiți un funkcionālo sistēmu rādītāji pacientu ar MS grupās attēloti 2.2. tabulā.

2.2. tabula

\section{EDSS kopvērtējuma un funkcionālo sistēmu vidējie rādītāji pacientu ar MS grupās}

\begin{tabular}{|c|c|c|c|c|c|c|c|c|c|}
\hline 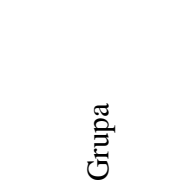 & 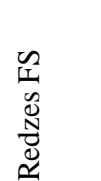 & 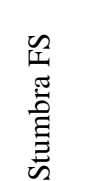 & 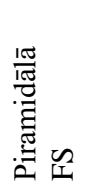 & 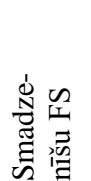 & 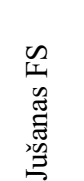 & 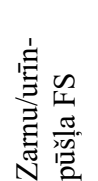 & 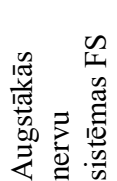 & 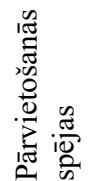 & $\begin{array}{l}\tilde{n} \\
\hat{\tilde{I}} \\
\text { }\end{array}$ \\
\hline MS ar RNN & 0,79 & 0,20 & 1,24 & 0,53 & 0,17 & 0,38 & 0,45 & 0,53 & 1,46 \\
\hline MS bez RNN & 0,44 & 0,44 & 1,51 & 0,52 & 0,23 & 0,36 & 0,45 & 0,69 & 1,88 \\
\hline $\mathrm{p}$ & $<0,05$ & $<0,05$ & $<0,05$ & 0,05 & 0,05 & 0,05 & 0,05 & 0,05 & $<0,05$ \\
\hline
\end{tabular}
EDSS - Izvērstā invaliditātes statusa skala (Expanded Disability Status Scale); FS funkcionālā sistēma; MS ar RNN - multiplās sklerozes pacienti ar redzes nerva neirītu anamnēzē; MS bez RNN - multiplās sklerozes pacienti bez redzes nerva neirīta anamnēzē; $\mathrm{p}$ - ticamības koeficients

Analizējot funkcionālo sistēmu vidējos rādītājus, tika konstatēts, ka pacientu ar MS grupām tie statistiski ticami atšḳīās redzes, smadzeṇu stumbra un piramidālajās funkcionālajās sistēmās $(\mathrm{p}<0,05)$. 


\subsection{Funkcionālie redzes sistēmas parametri}

\subsubsection{Redzes asums}

Pacientu ar MS grupā ar RNN anamnēzē vidējais ar lēcu koriǵētais redzes asums bija 0,93 (SD = 0,25) un mazākā korig̣êtā redzes asuma vērtība bija 0,02. Pacientu ar MS grupā bez RNN anamnēzē vidējais koriǵētais redzes asums bija ievērojami labāks - 1,02 (SD = 0,21), tomēr šajā grupā tikai 30 acīm (35\%) bija iespējams koriǵēt redzes asumu līdz 1 .

Salīdzinoši nelielam indivīdu skaitam no pacientu ar MS grupas, kas iepriekš pārcietuši RNN, tikai 7 acīm (10\%) bija iespējama redzes asuma korekcija $\geq 1$. Šajā grupā arī tikai 6 otras puses - RNN neskartās - acīm bija iespējama pilnīga redzes korekcija.

\subsubsection{Redzes izraisītie potenciāli}

Balstoties uz Starptautiskās Klīniskās neirofiziolog̣ijas federācijas ieteikumiem (Holder, Celesia, Miyake, Tobimatsu, and Weleber, 2010), lai izvairītos no neprecīzas mērījumu interpretācijas, pētījumā izmantotajai VEP aparatūrai bija nepieciešams noteikt precīzas N 75/P 100 amplitūdas un P 100 latences mērījumu robežvērtības.

Izmantojot ROC līknes analīzi un nosakot precīzo N 75/P 100 amplitūdas robežvērtību kontroles grupai un ar MS slimajiem pacientiem, secināts, ka tā ir 10,52 mkV (AUC = 0,81; 95\% TI: 0,76-0,86; $\mathrm{Se}=0,91 ; \mathrm{Sp}=0,63$; maksimālais Joudena indekss ir 0,54). Minētā ROC līkne N 75/P 100 amplitūdas robežvērtības noteikšanai atspoguḷota 2.2. attēlā. 


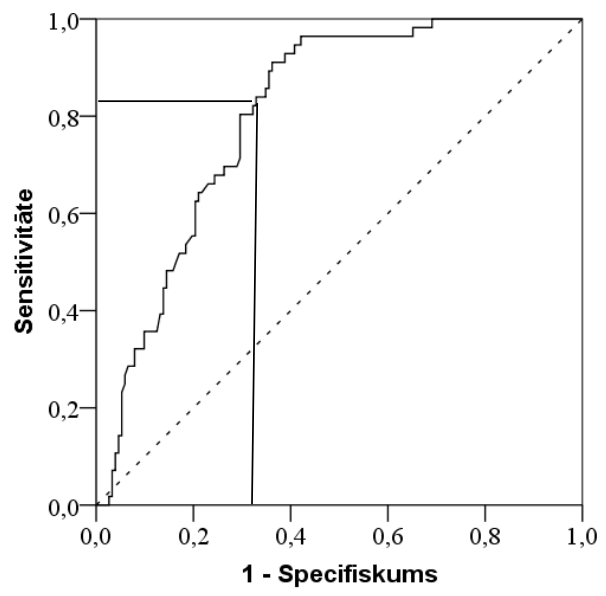

2.2. attēls. ROC līkne $\mathbf{N}$ 75/P 100 amplitūdas robežvērtības noteikšanai

Līdzīgi nosakot precīzu P 100 latences robežvērtību kontroles grupai un ar MS slimajiem pacientiem, secināts, ka tā ir 110,25 ms (AUC = 0,86; 95\% TI: 0,80-0,91; $\mathrm{Se}=0,63 ; \mathrm{Sp}=0,96 ;$ maksimālais Joudena indekss ir 0,59). Šì līkne redzama 2.3. attēlā.

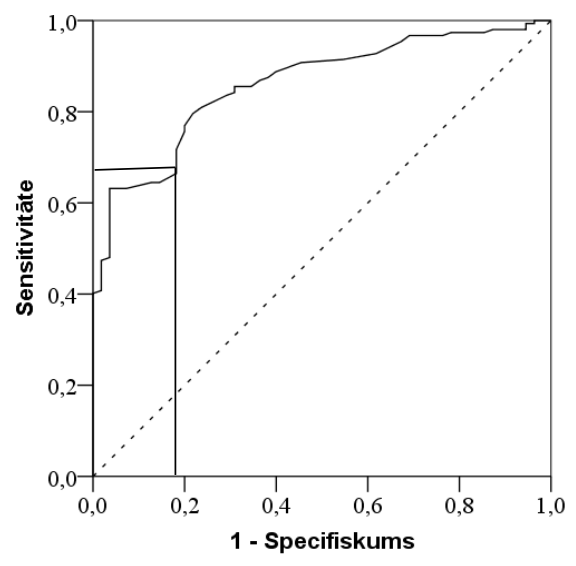

2.3. attēls. ROC līkne $\mathbf{P} \mathbf{1 0 0}$ latences robežvērtības noteikšanai 
Veiktajos VEP izmeklējumos N 75/P 100 amplitūda, kas bija zemāka par 10,52 mkV, tika uzskatīta par pazeminātu. P 100 latence, kas bija garāka par $110,25 \mathrm{~ms}$, tika uzskatīta par pagarinātu.

Analizējot vidējās N 75/P 100 VEP amplitūdas rādītājus pētījuma grupās, tika konstatēts, ka zemākā amplitūda vērojama ar MS slimo pacientu grupāa ar RNN anamnēzē, turklāt tieši RNN (+) acīm. Šo pacientu acīm vidējā N 75/P 100 amplitūda bija 8,16 mkV (SD =4,60). Taču arī ar MS slimo pacientu grupā, kurā RNN klīniskās epizodes nekad nav bijis, vēroja zemāku vidējo N 75/P 100 amplitūdu, salīdzinot ar kontroles grupu. Balstoties uz neatkarīgo izlašu t testu, secināts, ka vidējā N 75/P 100 amplitūda kontroles grupai ( $\mathrm{M}=$ $14,51 ; \mathrm{SD}=3,35)$ un ar MS slimo pacientu grupai bez RNN anamnēzē $(\mathrm{M}=$ 9,86; SD = 4,63) atšķiras vidēji par 4,65 mkV un šī atšķirība ir statistiski ticama ( $\mathrm{p}<0,001)$. Balstoties uz ROC līknes analīzi, novērtējot atšķirību starp abām grupām, secināts, ka tā ir statistiski laba $(\mathrm{AUC}=0,81 ; 95 \%$ TI: $0,74-0,88$; $\mathrm{p}<$ $0,001)$.

Analizējot abas ar MS slimo pacientu grupas, secināts, ka RNN (+) acīm $(\mathrm{M}=8,16 ; \mathrm{SD}=4,60)$ un acīm bez iepriekš pārciesta $\mathrm{RNN}(\mathrm{M}=9,86$; $\mathrm{SD}=4,63)$ vidējā N 75/P 100 amplitūda statistiski ticami $(\mathrm{p}=0,03)$ atšķiras vidēji par $1,70 \mathrm{mkV}$. Tomēr, balstoties uz ROC līknes analīzi un izvērtējot statistisko atškirīibu starp abām grupām, secināts, ka tā ir vāja (AUC = 0,65; 95\% TI: $0,60-0,70 ; \mathrm{p}<0,001)$.

Analizējot ar MS slimo pacientu grupu, kurai ir RNN anamnēzē, secināts, ka vidējā N 75/P 100 amplitūda RNN (+) acīm (M = 8,16; SD = 4,60) un RNN (-) $\operatorname{acīm}(\mathrm{M}=11,03 ; \mathrm{SD}=5,40)$ atšķiras vidēji par 2,87 mkV un šī atšḳirība ir statistiski ticama $(\mathrm{p}=0,01)$. Balstoties uz ROC līknes analīzi un novērtējot abu grupu statistisko atškirīibu, secināts, ka tā ir vāja, bet statistiski ticama (AUC = 0,65; 95\% TI: 0,51-0,78; p <0,001).

Ṇemot vērā noteikto vidējās N 75/P 100 amplitūdas robežvērtību 10,52 mkV, ar MS slimo pacientu grupā bez iepriekš pārciesta RNN pazemināta 
amplitūda tika konstatēta 54 acīm (62,79\%). Analizējot vidējo N 75/P 100 amplitūdu ar MS slimo pacientu grupā, kas iepriekš pārcietuši RNN, tika iegūti šādi rezultāti. Lielākajai daḷai - 23 RNN (+) acīm (69,69 \% no RNN (+) acīm) novēroja pazeminātu vidējo N 75/ P100 amplitūdu, taču arī 18 (54,54\%) otrajās - RNN tieši neskartajās - acīs tika konstatēta patoloǵiski samazināta vidējā VEP amplitūda.

Līdzīgi analizējot vidējo VEP rādītāju P 100 latenci, konstatēts, ka izteiktākais tās pagarinājums vērojams ar MS slimo pacientu grupā, kas pārcietuši RNN, RNN (+) acīm - 12600 ms (SD = 18,26), taču arī pacientu grupā bez RNN anamnēzē P 100 latence bija garāka $(\mathrm{M}=116,73$; SD = 16,00), salīdzinot ar kontroles grupu $(\mathrm{M}=101,81 ; \mathrm{SD}=5,66)$.

Salīdzinot vidējo P100 latenci RNN (+) acīm ar šo rādītāju pacientu ar MS grupā, kurā RNN nekad nav bijis, konstatēts, ka RNN skartajās acīm P 100 latence ir vidēji par 9,26 ms garāka un š̄ atškirīiba ir statistiski ticama ( $\mathrm{p}<0,01)$. Novērtējot šīs atškiirības statistisko efektu abām MS pacientu grupām, secināts, ka tas ir vājšs, bet statistiski ticams (AUC $=0,64 ; 95 \%$ TI: 0,55-0,72; p $<0,001)$.

Atsevišķi analizējot pacientu ar MS grupu, kas iepriekš pārcietuši RNN, secināts, ka vidējā P 100 latence statistiski ticami ( $\mathrm{p}<0,01)$, par vidēji 11,25 ms, atšķiras RNN (+) acīm (M = 126,00; $\mathrm{SD}=18,26)$ un $\mathrm{RNN}(-)$ acīm $(\mathrm{M}=114,75$; $\mathrm{SD}=11,94)$. Tomēr, novērtējot šīs atškirīibas statistisko efektu, secināts, ka tas ir vājš, bet statistiski ticams (AUC $=0,68 ; 95 \%$ TI: $0,55-0,81$; $\mathrm{p}<0,001)$.

Ṇemot vērā noteikto P 100 latences robežvērtību - 110,25 ms, tika secināts, ka pacientu ar MS grupā bez iepriekš pārciesta RNN 52 acīm (60,47\%) šis rādītājs ir patoloǵiski pagarināts. Taču pacientu ar MS grupā, kas pārcietuši RNN, P 100 latences patologisku pagarinājumu vēroja ne tikai 25 acīm (75,75\% no RNN (+) acīm) pēc RNN epizodes, bet arī 19 acīm (57,57\% no RNN (-) acīm), kurās RNN klīnisko pazīmju nebija bijis. 
Pētījumā iegūto pētījuma grupu VEP rādītāju apkopojums atspogulots 2.3. tabulā.

2.3. tabula

\section{Redzes izraisīto potenciālu rezultāti}

\begin{tabular}{lcccc} 
& $\begin{array}{c}\text { RNN(+), } \\
\text { acis } \\
(\mathrm{N}=33)\end{array}$ & $\begin{array}{c}\text { RNN(-), } \\
\text { acis } \\
(\mathrm{N}=33)\end{array}$ & $\begin{array}{c}\text { MS bez } \\
\text { RNN, acis } \\
(\mathrm{N}=86)\end{array}$ & $\begin{array}{c}\text { Kontrole, } \\
\text { acis } \\
(\mathrm{N}=56)\end{array}$ \\
\hline $\begin{array}{l}\text { Vidējā N 75/ } \\
\text { P 100 amplitūda, }\end{array}$ & 8,16 & 11,03 & 9,86 & 14,51 \\
mkV, ( \pm SD) & $(4,6)$ & $(5,4)$ & $(4,63)$ & $(3,35)$ \\
\hline $\begin{array}{l}\text { Vidējā P 100 } \\
\text { latence, ms, } \\
( \pm \text { SD })\end{array}$ & 126,0 & 114,75 & 116,73 & 101,81 \\
\hline
\end{tabular}

mkV - mikrovolts; ms - milisekunde; MS bez RNN - multiplās sklerozes pacienti bez redzes nerva neirīta anamnēzē; $\mathrm{N}$ - kopējais skaits; $\mathrm{RNN}(-)$ - acis bez redzes nerva neirīta anamnēzē; RNN (+) - acis ar redzes nerva neirītu anamnēzē; SD - standartnovirze (standard deviation)

\subsubsection{Krāsu redzes izmaiṇas}

Analizējot krāsu redzes izmaiņas, konstatēts, ka ar MS slimo pacientu grupā bez iepriekš pārciesta RNN 12 acīm $(13,95 \%)$ novēroja traucētu krāsu redzi. Nedaudz biežāk, 11 RNN (+) acīm $(33,33 \%$ no RNN (+) acīm), krāsu redze traucēta ar MS slimo pacientu grupā ar RNN anamnēzē. Balstoties uz Pīrsona hī kvadrāta statistisko analīzi, secināts, ka pacienta piederība noteiktai grupai ietekmē krāsu redzi $(\mathrm{p}<0,01)$ un efekta lielums ir vidējs $(\varphi=0,27)$. Balstoties uz statistisko analīzi, secināts, ka RNN esamība statistiski ticami ietekmē krāsu redzi $(\mathrm{p}<0,01)$ un efekta lielums ir statistiski liels $(\varphi=0,35)$. Kontroles grupā krāsu redzes traucējumus nekonstatēja.

\subsubsection{Redzes lauku izmaiņas}

Analizējot datorizētās perimetrijas rezultātus, konstatēts, ka biežākais redzes lauku traucējuma veids ir paracentrālas skotomas. Tikai vienā RNN skartajā acī pacientu ar MS grupā pēc pārciesta RNN tika novērots arkveida 
redzes lauka defekts. Pacientu ar MS grupā bez iepriekš pārciesta RNN paracentrālas skotomas konstatētas 55 acīs (63,95\%). Šādi traucējumi tika konstatēti arī lielākajai daḷai RNN skartajām acīm (81,81\% no RNN (+) acīm) MS pacientu grupā ar RNN anamnēzē. Turklāt paracentrālas skotomas tika konstatētas arī pusei to acu, kurās RNN epizode nebija novērota $(57,57 \%$ no RNN (-) acīm). Balstoties uz Pīrsona hī kvadrāta statistisko analīzi, secināts, ka RNN esamība statistiski ticami neietekmē izmaiņas redzes laukos $(p=0,11)$, tomēr statistiskā efekta lielums ir vidējs $(\varphi=0,20)$. Redzes lauku izmaiṇas kontroles grupā netika novērotas.

\subsection{Strukturāli redzes sistēmas parametri}

\subsubsection{Redzes nerva diska nobālējums fundus oculi apskatē}

Analizējot izmaiņas fundus oculi apskatē, konstatēts, ka ar MS slimiem pacientiem grupā bez iepriekš pārciesta RNN redzes nerva diska nobālējums atrasts 19 acīs (22,09\%). Atsevišḳi analizējot ar MS slimu pacientu grupu ar iepriekš pārciestu RNN, konstatēts, ka redzes nerva diska nobālējumu biežāk vēro RNN (+) acīs (7 acīs jeb 24,24\% no RNN (+) acīm), salīdzinot ar RNN (-) acīm (4 acīs jeb 15,15\% no RNN (-) acīm). Balstoties uz Pīrsona hī kvadrāta statistisko analīzi, secināts, ka RNN esamība anamnēzē neietekmē redzes nerva diska nobālējumu $(\mathrm{p}=0,80)$. Manna-Vitnija neparametriskais tests norāda, ka laika periodam pēc RNN epizodes nav ietekmes uz redzes nerva diska nobālējuma parādīšanos $(\mathrm{p}=0,18)$.

\subsubsection{Tīklenes nervu šḳiedru slāṇa mērījumi ar OCT}

Veicot izmeklējumus ar optiskās koherences tomogrāfijas metodi un balstoties uz kovariatīvo multivariatīvo dispersiju analīzi (MANCOVA), secināts, ka, vienlaikus analizējot RNFL rādītāju kopumu (RNFL biezumu 
temporālajā, nazālajā, augšejā un apakšējā kvadrantos), tas statistiski ticami (Pillai's trace $=0,26 ; \mathrm{F}(12,340)=4,41 ; \mathrm{p}<0,001)$ atšḳiras 2 pētījumā iekḷautajām ar MS slimo pacientu grupām, turklāt vecums ir statistiski ticami šo sistēmu ietekmējošais faktors $(\mathrm{p}<0,01)$.

Analizējot vidējo RNFL biezumu visām pētījuma grupām, konstatēts, ka šis slānis visplānākais ir acīs ar iepriekš pārciestu RNN (M = 85,63; SD = 16,51), taču arī ar MS slimo pacientu grupā bez iepriekš zināmas RNN epizodes vidējais RNFL biezums bija plānāks ( $\mathrm{M}=90,16$; SD = 11,18), salīdzinot ar kontroles grupu (M=98,76; SD =7,12). Vidējā RNFL biezuma rādītāji pētījuma grupām atspogul,oti 2.4. tabulā

2.4. tabula

\section{Vidējais RNFL biezums pētījuma grupās}

\begin{tabular}{|c|c|c|c|c|c|}
\hline Grupa & $\mathrm{N}$, acis & $\begin{array}{l}\text { Vidējais } \\
\text { RNFL } \\
\text { biezums, } \\
\text { mkm } \\
\text { ( } \pm \text { SD) }\end{array}$ & $\begin{array}{l}\text { Mini- } \\
\text { mums, } \\
\text { mkm }\end{array}$ & $\begin{array}{l}\text { Maksi- } \\
\text { mums, } \\
\text { mkm }\end{array}$ & p vērtība \\
\hline Kontroles & 56 & $\begin{array}{l}98,76 \\
(7,12)\end{array}$ & 88 & 117 & \\
\hline $\begin{array}{l}\text { MS ar RNN, } \\
\text { RNN (+) }\end{array}$ & 33 & $\begin{array}{l}85,63 \\
(16,51)\end{array}$ & 48 & 133 & $<0,001$ \\
\hline MS bez RNN & 86 & $\begin{array}{l}90,16 \\
(11,18)\end{array}$ & 66 & 115 & \\
\hline
\end{tabular}

mkm - mikrometrs; MS ar RNN - multiplās sklerozes pacienti ar redzes nerva neirītu anamnēzē; MS bez RNN - multiplās sklerozes pacienti bez redzes nerva neirīta anamnēzē; N - kopējais skaits; p - ticamības koeficients; RNFL - tīklenes nervu šķiedru slānis; RNN (+) - acis ar redzes nerva neirītu anamnēzē; SD - standartnovirze (standard deviation)

Analizējot vidējā RNFL biezuma vērtības dažādos kvadrantos (augšèjā, apakšejā, temporālajā (RNFLT), nazālajā (RNFLN)), tika iegūti šādi rezultāti. Salīdzinot kontroles grupu un pacientu ar MS grupu, kam konstatēts RNN 
anamnēzē (tikai RNN (+) acis), secināts, ka visos kvadrantos RNFL biezums statistiski ticami atšķiras $(\mathrm{p}<0,05)$, un, balstoties uz ROC līknes analīzi, secināts, ka visvairāk RNFL biezums atšḳiras temporālajā kvadrantā (atbilstoši AUC $=0,78 ; 95 \%$ TI: 0,67-0,89; $\mathrm{p}<0,01)$. Vidējā RNFL biezuma ROC līknes temporālajā, nazālajā, augšējā un apakšèjā kvadrantā atspoguḷotas 2.4. attēlā.

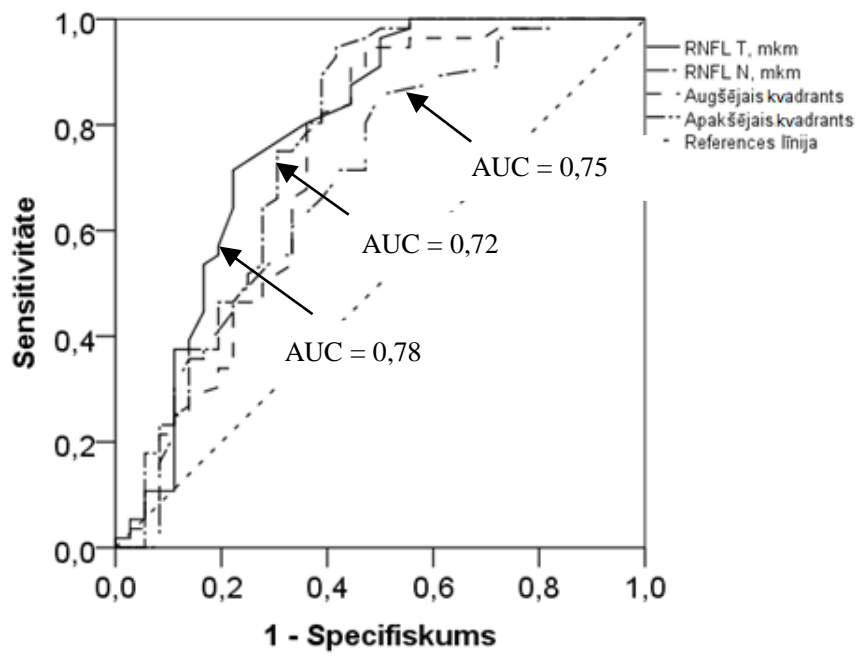

\section{4. attēls. Vidējā RNFL biezuma ROC līknes temporālajā, nazālajā, augšējā un apakšējā kvadrantā}

AUC - laukums zem līknes; mkm - mikrometrs; RNFLN - tīklenes nervu šḳiedru slānis nazālajā kvadrantā; RNFLT - tīklenes nervu škiedru slānis temporālajā kvadrantā

Savukārt līdzīgā veidā salīdzinot kontroles grupu un ar MS slimu pacientu grupu bez RNN anamnēzēe, secināts, ka arī šajās grupās visi RNFL biezuma rādītāji statistiski ticami atšķiras ( $\mathrm{p}<0,05)$. Turklāt, līdzīgi kā iepriekš, abām grupām vislielāko RNFL biezuma atškirīību novēroja temporālajā kvadrantā (AUC = 0,69; 95\% TI: 0,60-0,77; p < 0,01).

RNFL vidējais biezums mkm augšējā, apakšèjā, temporālajā un nazālajā kvadrantā dažādās pētījuma grupās attēlots 2.5. tabulā. 
2.5. tabula

RNFL vidējais biezums dažādos kvadrantos

\begin{tabular}{llllc} 
Grupa & $\begin{array}{c}\text { RNFLT } \\
( \pm \mathrm{SD}), \\
\mathrm{mkm}\end{array}$ & $\begin{array}{c}\text { RNFLN } \\
( \pm \mathrm{SD}), \\
\mathrm{mkm}\end{array}$ & $\begin{array}{c}\text { Augšejais } \\
\text { kvadrants } \\
( \pm \mathrm{SD}), \\
\mathrm{mkm}\end{array}$ & $\begin{array}{c}\text { Apakšejais } \\
\text { kvadrants } \\
( \pm \mathrm{SD}), \\
\mathrm{mkm}\end{array}$ \\
\hline Kontroles & 70,92 & 75,25 & 121,01 & 127,74 \\
& $(9,49)$ & $(10,91)$ & $(12,06)$ & $(13,66)$ \\
\hline MS ar & 56,44 & 68,30 & 107,47 & 110,33 \\
RNN, & $(15,93)$ & $(20,12)$ & $(22,63)$ & $(23,99)$ \\
RNN $(+)$ & & & & \\
\hline MS bez & 62,12 & 69,15 & 111,58 & 118,70 \\
RNN & $(13,50)$ & $(13,05)$ & $(16,64)$ & $(18,93)$ \\
\hline
\end{tabular}

mkm - mikrometrs; MS ar RNN - multiplās sklerozes pacienti ar redzes nerva neirītu anamnēzē; MS bez RNN - multiplās sklerozes pacienti bez redzes nerva neirīta anamnēzē; RNFLN - tīklenes nervu šķiedru slānis nazālajā kvadrantā; RNFLT - tīklenes nervu šçiedru slānis temporālajā kvadrantā; RNN (+) - acis ar redzes nerva neirītu anamnēzē; SD - standartnovirze (standard deviation)

Balstoties uz OCT aparātā iekḷauto normatīvo datubāzi, tika analizēts indivīdu skaits ar samazinātu RNFLT biezumu. Samazināts RNFLT biezums tika konstatēts 33\% acu - gan ar MS slimo pacientu grupā ar RNN anamnēzēe, gan ar MS slimo pacientu grupā bez iepriekš pārciesta RNN.

\subsubsection{Redzes nerva demielinizācija un demielinizējošu perēkḷu skaits magnētiskās rezonanses izmeklējumā}

MRI galvas un muguras smadzenēm, kā arī redzes nerviem tika veikts 50 ar MS slimajiem pacientiem, tātad tika analizēti 100 redzes nervi. MRI tika veikts 28 pacientiem ar RNN anamnēzē un 22 pacientiem bez RNN anamnēzē. Analizējot redzes nervu izmeklējumu rezultātus MRI, secināts, ka ar MS slimo pacientu grupā, kas pārcietuši RNN, 27 acīs (96,42\% no RNN (+) acīm) MRI attēlos bija vērojama unilaterāla redzes nerva demielinizācija. Tomēr arī 4 ar MS slimu pacientu bez RNN epizodes anamnēzē acīs $(9,09 \%$ pacientu ar MS grupā bez RNN anamnēzē acīm) MRI izmeklējumā tika konstatētas demielinizācijas pazīmes. Analizējot vidējo demielinizējošu perēkḷu skaitu galvas un muguras 
smadzenēs, konstatēts, ka statistiski ticami vairāk perēkḷu periventrikulāri, jukstakortikāli, infratentoriāli un muguras smadzeņu kakla daḷā bija pacientiem ar MS bez RNN anamnēzē ( $\mathrm{p}<0,05$ ). Vidējais demielinizējošu perēkḷu skaits dažādās lokalizācijās abās pacientu ar MS grupās attēlots 2.6. tabulā.

2.6. tabula

\section{Vidējais demielinizējošu perēkḷu skaits galvas un muguras smadzenēs pacientu ar MS grupās}

\begin{tabular}{lccccccc} 
Grupa & $\begin{array}{c}\text { Periven- } \\
\text { trikulāri }\end{array}$ & $\begin{array}{c}\text { Juksta- } \\
\text { kortikāli }\end{array}$ & $\begin{array}{c}\text { Infraten- } \\
\text { toriāli }\end{array}$ & $\begin{array}{c}\text { Kakla } \\
\text { daḷa }\end{array}$ & $\begin{array}{c}\text { Krūšu } \\
\text { dą̧a }\end{array}$ & $\begin{array}{c}\text { Conus } \\
\text { medul- } \\
\text { laris }\end{array}$ & $\begin{array}{c}\text { Kopējais } \\
\text { perēklu } \\
\text { skaits }\end{array}$ \\
\hline $\begin{array}{l}\text { MS } \\
\text { ar RNN }\end{array}$ & 5,12 & 1,67 & 1,15 & 1,79 & 1,15 & 0,27 & 11,27 \\
\hline $\begin{array}{l}\text { MS bez } \\
\text { RNN }\end{array}$ & 8,37 & 2,86 & 2,00 & 2,67 & 1,88 & 0,37 & 18,33 \\
\hline $\mathrm{p}$ & $<0,05$ & $<0,05$ & $<0,05$ & $<0,05$ & $>0,05$ & $>0,05$ & $<0,05$ \\
\hline
\end{tabular}

MS ar RNN - multiplās sklerozes pacienti ar redzes nerva neirītu anamnēzē MS bez RNN - multiplās sklerozes pacienti bez redzes nerva neirīta anamnēzē $\mathrm{p}$ - ticamības koeficients

Atsevišķi analizējot demielinizējošus perēkḷus, kuri atrodas redzes ceḷos, konstatēts, ka vidējais demielinizējošu perēkḷu skaits abās pacientu ar MS grupās statistiski ticami neatšḳīrās ( $\mathrm{p}>0,05)$.

\subsection{Aferento redzes sistēmu un slimību raksturojošo rādītāju savstarpējā saistība}

Lai izpētītu slimības ilguma ietekmi uz tīklenes nervu šķiedru slāņa biezumu, tika veikta Pīrsona korelācijas koeficienta analīze. Tika secināts, ka pacientu ar MS grupai ar RNN anamnēzē starp RNFLT biezumu un slimības ilgumu mēnešos pastāv vidēja, negatīva un statistiski ticama korelācija $\left(\mathrm{r}_{\mathrm{s}}=-0,38 ; \mathrm{p}=0,02\right)$. Līdzīgi analizējot pacientu ar MS grupu bez iepriekš pārciesta RNN, secināts, ka starp RNFL biezumu temporālajā kvadrantā un 
slimības ilgumu mēnešos pastāv vāja, negatīva, bet statistiski ticama korelācija $\left(\mathrm{r}_{\mathrm{s}}=-0,26 ; \mathrm{p}=0,01\right)$.

Vēloties izpētìt, vai pacienta neirologiskais stāvoklis ir saistîts ar izmaiṇām tīklenē, tika izmantota Spīrmena korelācijas koeficienta analīze un aprēkināta RNFLT biezuma korelācija ar pacienta, kas slims ar MS, invaliditātes pakāpi. Tika secināts, ka pacientiem ar MS un RNN anamnēzē starp RNFLT biezumu un invaliditātes pakāpi raksturojošo EDSS kopvērtējuma skaitli pastāv vidēja, negatīva un statistiski ticama korelācija $\left(r_{s}=-0,35 ; p=0,03\right)$. Līdzīga savstarpēja sakarība $\left(\mathrm{r}_{\mathrm{s}}=-0,32 ; \mathrm{p}<0,01\right)$ konstatēta arī pārējiem pacientiem ar MS grupā bez RNN pazīmēm anamnēzē.

Atsevišḳi analizējot EDSS funkcionālo sistēmu rādītāju korelāciju ar RNFLT biezumu abās pacientu ar MS grupās, neizdevās konstatēt statistiski ticamas korelācijas $(\mathrm{p}>0,05)$.

Lai noskaidrotu tīklenes nervu šḳiedru slāņa biezuma saistību ar redzes asuma funkciju, tika veikta Pīrsona korelācijas koeficienta analīze. Secināts, ka pacientu ar MS grupai bez RNN anamnēzē starp RNFLT biezumu un koriǵētu redzes asumu pastāv vidēja, pozitīva un statistiski ticama korelācija $(r=0,30$; p < 0,01). Līdzīgi secināts, ka pacientu ar MS grupā ar RNN anamnēzi acīs, kuras RNN klīnisko pazīmju nav bijis, starp RNFLT biezumu un redzes asumu pastāv vidēja, pozitīva un statistiski ticama korelācija $(r=0,30 ; \mathrm{p}<0,01)$. Tomēr acīs, kurās bija novērotas RNN klīniskās pazīmes, starp RNFLT biezumu un korig̣ētu redzes asumu statistiski ticama korelācija netika pierādīta $(\mathrm{p}=0,57)$.

Noskaidrojot, vai tīklenes struktūras izmaiņas ietekmē krāsu redzes funkciju, tika konstatēts, ka pacientu ar MS grupā starp samazinātu RNFLT biezumu un izmainītu krāsu redzi pastāv statistiski ticama sakarība $(\mathrm{p}<0,05)$, taču efekta lielums ir mazs $(\varphi=0,23)$. Kopumā tikai 16 acīs $(10,53 \%)$ no visām pacientu ar MS acīm novēroja vienlaicīgu RNFLT biezuma samazinājumu un krāsu redzes traucējumus. 
Analizējot visus ar MS slimos pacientus, tika novērota statistiski ticama sakarība $(\mathrm{p}<0,05)$ starp samazinātu RNFLT biezumu un izmainītiem redzes laukiem, taču efekta lielums ir mazs $(\varphi=0,18)$. Kopumā $40(26,32 \%)$ pacientu ar MS acīs vēro gan samazinātu RNFLT biezumu, gan izmaiņas datorizētajā redzes lauku perimetrijā. Tomēr $61(40,13 \%)$ pacienta acīs ir traucēti redzes lauki, taču RNFLT biezums ir normas robežās.

Analizējot samazināta RNFLT biezuma saistību ar VEP rezultātiem pacientu ar MS grupā bez RNN anamnēzē, samazināta N 75/P 100 amplitūda tika konstatēta $54(62,7 \%)$ acīs, taču samazināts RNFLT biezums bija tikai 29 (33,7\%) acīs. Izrādījās, ka šajā grupā arī 29 (33,7\%) pacientu acīs, kurām tika atrasta samazināta N 75/P100 amplitūda, RNFLT biezums bija normas robežās, taču vienlaikus normāla amplitūda un samazināts RNFLT biezums tika atrasts tikai 4 (4,6\%) pacientu acīs. Patoloǵiski samazināti abi rādītāji bija 25 (29,07\%) š̄is grupas pacientu acīs.

Līdzīgi analizējot VEP P 100 latenci pacientu ar MS grupā bez iepriekš pārciesta RNN, tika konstatēts, ka normāls RNFLT biezums un pagarināta $\mathrm{P} 100$ latence ir $27(31,4 \%)$ pacientu acīs, taču normāla P100 latence un vienlaikus samazināts RNFLT biezums tika atrasts tikai 4 (4,6\%) pacientu acīs.

Analizējot pacientu ar MS grupu ar RNN anamnēzē RNN (+) acis, secināts, ka normāls RNFLT biezums un samazināta N 75/P 100 amplitūda atrasta $11(33,33 \%)$ pacientu acīs, taču normāla VEP amplitūda vienlaikus ar samazinātu RNFLT biezumu atrasta tikai 2 (5,56\%) pacientu acīs. Analizējot P 100 latenci RNN skartajās acīs, secināts, ka tā ir pagarināta 12 (36,11\%) pacientu acīs, kurās ir normāls RNFLT biezums. Taču tikai $2(5,56 \%)$ pacientu acīs ar samazinātu RNFLT biezumu atrasta normāla P 100 latence.

Balstoties uz Spīrmena korelācijas koeficienta analīzi, secināts, ka starp RNFLT biezumu un vidējo N 75/P 100 amplitūdu pacientu ar MS bez RNN grupā pastāv vidēja, pozitīva un statistiski ticama korelācija $\left(\mathrm{r}_{\mathrm{s}}=0,43\right.$; $\mathrm{p}<0,001)$. Līdzīga korelācija novērota pacientu ar MS grupā ar pārciestu RNN 
RNN (+) acīs $\left(\mathrm{r}_{\mathrm{s}}=0,45 ; \mathrm{p}<0,001\right)$. Turklāt arī RNN (-) acīs starp RNFLT biezumu un vidējo N 75/P 100 amplitūdu tika atrasta vidēja, pozitiva un statistiski ticama korelācija $\left(\mathrm{r}_{\mathrm{s}}=0,35 ; \mathrm{p}=0,04\right)$.

Līdzīgi analizējot vidējās P 100 latences saistību ar RNFLT biezumu, konstatēts, ka gan pacientiem ar MS bez RNN anamnēzē $\left(r_{s}=-0,40 ; p<0,001\right)$, gan RNN (+) acīs starp šiem rādītājiem pastāv vidēja, negatīva un statistiski ticama korelācija $\left(\mathrm{r}_{\mathrm{s}}=-0,55 ; \mathrm{p}<0,001\right)$. Arī $\mathrm{RNN}(-)$ acīs tika atrasta vidēja, negatīva un statistiski ticama korelācija $\left(\mathrm{r}_{\mathrm{s}}=-0,32 ; \mathrm{p}=0,04\right)$.

Lai noskaidrotu labāko metodi anamnestiska RNN apstiprināšanai un izmantojot RNN klīniskās pazīmes kā zelta standartu RNN diagnostikā, tika aprēḳināta VEP un OCT rādītāju diagnostiskā lietderība.

Visaugstāko sensitivitāti $(76,19 \%)$ klīniska RNN apstiprināšanai un arī salīdzinoši augstu specifiskumu (95,83\%) uzrādīja pagarināta P 100 latence. Nedaudz mazāka bija pazeminātas N 75/P 100 amplitūdas sensitivitāte un specifiskums (attiecīgi 72,22\% un 91,07\%). Analizējot samazinātu RNFLT biezumu klīniska RNN apstiprināšanai, tika noskaidrots, ka tā sensitivitāte ir tikai 44,44\%, taču šim rādītājam bija ḷoti augsts specifiskums - 100\%. Samazināts RNFLT biezums uzrādīja arī augstāko pozitīvo paredzamo vērtību RNN apstiprināšanai - 100\%. Minēto VEP un OCT rādītāju novērtējums atspoguḷots 2.7. tabulā.

2.7. tabula

VEP un OCT metožu sensitivitātes, specifiskuma un precizitātes raksturojums

\begin{tabular}{|c|c|c|c|c|c|}
\hline $\begin{array}{l}\text { Rādī } \\
\text { tājs }\end{array}$ & $\begin{array}{c}\text { Sensitivitāte } \\
\qquad \%) \\
{[95 \% \mathrm{TI}]}\end{array}$ & $\begin{array}{c}\text { Specifiskums } \\
(\%) \\
{[95 \% \mathrm{TI}]}\end{array}$ & $\begin{array}{c}\text { Diagnostiskā } \\
\text { precizitāte } \\
(\%)\end{array}$ & $\begin{array}{c}\text { Pozitīva } \\
\text { paredzamā vērtība } \\
(\%) \\
{[95 \% \mathrm{TI}]}\end{array}$ & $\begin{array}{c}\text { Negatīva } \\
\text { paredzamā } \\
\text { vērtība } \\
(\%) \\
{[95 \% \mathrm{TI}]}\end{array}$ \\
\hline $\begin{array}{l}\text { Pazemināta } \\
\text { N 75/P } 100 \\
\text { amplitūda }\end{array}$ & $\begin{array}{c}72,22 \\
{[54,81-85,78]}\end{array}$ & $\begin{array}{c}91,07 \\
{[80,37-97,00]}\end{array}$ & 83,70 & $\begin{array}{c}83,87 \\
{[66,26-94,49]}\end{array}$ & $\begin{array}{c}83,61 \\
{[71,91-} \\
91,83]\end{array}$ \\
\hline
\end{tabular}


2.7. tabulas turpinājums

\begin{tabular}{lccccc}
\hline Pagarināta & 76,19 & 95,83 & 86,00 & 94,12 & 82,14 \\
P 100 & {$[52,83-91,69]$} & {$[78,81-99,30]$} & & {$[71,24-99,02]$} & {$[63,09-$} \\
latence & & & & & $93,87]$ \\
\hline Samazināts & 44,44 & 100 & 78,00 & 100 & 56 \\
RNFLT & {$[27,95-61,90]$} & {$[93,56-100]$} & & {$[79,24-100]$} & {$[62,32-$} \\
biezums & & & & & $83,12]$ \\
\hline
\end{tabular}

RNFLT - tīklenes nervu škiedru slānis temporālajā kvadrantā; TI - ticamības intervāls

Veicot noteikto VEP un OCT rādītāju vērtējumu, izmantojot ROC līkṇu analīzi, secināts, ka piemērotākais diagnostiskais tests klīniska RNN apstiprināšanai ir vidējās VEP P 100 latences izmantošana (AUC $=0,92 ; 95 \%$ TI: 0,86-0,98; p < 0,001), tālāk seko vidējā N 75/P 100 amplitūda (AUC = 0,85; 95\% TI: 0,76-0,94; p < 0,001), un kā salīdzinoši vājākā metode RNN apstiprināšanai ir RNFLT biezuma noteikšana $($ AUC $=0,78 ; 95 \%$ TI: 0,68-0,90; $\mathrm{p}<0,001)$.

Lai noskaidrotu, vai makroskopiskas izmaiņas fundus oculi atspoguḷojas OCT rezultātos, tika analizēta samazināta RNFLT biezuma korelācija ar temporālu redzes nerva diska nobālējumu. Veicot šos aprēķinus, tika secināts, ka starp abiem šiem rādītājiem abās pacientu ar MS grupās pastāv statistiski ticama sakarība $(p<0,05)$ un efekta lielums ir vidējs $(\varphi=0,33)$. Biežāk vienlaikus samazinātu RNFLT biezumu un redzes nerva diska nobālējumu novēroja pacientu acīs pēc RNN epizodes (28 acīs jeb 87,50\% no RNN (+) acīm).

Precizējot samazināta RNFLT biezuma saistību ar MRI rezultātiem un analizējot pacientu ar MS abu grupu datus, konstatēts, ka tikai 15 acīs (15\% no ar MRI izmeklēto acu skaita) vienlaikus ar redzes nerva demielinizāciju MRI izmeklējumā bija novērots arī samazināts RNFLT biezums OCT izmeklējumā. Turklāt 16 acīs (16\% no ar MRI izmeklēto acu skaita) pacientiem ar vizuāli izmainītu redzes nervu MRI bija konstatēts normāls RNFLT biezums. Savukārt 24 acīs (24\% no ar MRI izmeklēto acu skaita) MRI redzes nerva bojājumu neuzrādīja, bet bija vērojams samazināts RNFLT biezums. 
Balstoties uz Pīrsona hī kvadrāta statistisko testu, secināts, ka starp redzes nerva bojājuma pazīmēm MRI un samazinātu RNFLT biezumu statistiski ticama korelācija nepastāv $(p=0,24)$ un efekta lielums ir mazs $(\varphi=0,11)$.

Līdzīgi analizējot radiologisko redzes nervu izmaiņu saistību ar VEP amplitūdu, konstatēts, ka 17 gadījumos (17\% no ar MRI izmeklēto acu skaita) MRI redzes nerva bojājuma pazīmes atrodamas vienlaikus ar samazinātu VEP amplitūdu, tomēr salīdzinoši biežāk - 42 gadījumos (42\% no ar MRI izmeklēto acu skaita) - pazeminātu amplitūdu konstatē pacientiem ar neizmainītiem redzes nerviem MRI.

Līdzīgi kā iepriekš secināts, ka starp redzes nerva izmaiņām MRI un izmainītu VEP amplitūdu nepastāv statistiski ticama korelācija $(\mathrm{p}=0,66)$ un efekta lielums ir mazs $(\varphi=0,04)$.

Ṇemot vērā demielinizācijas ietekmi uz P 100 latenci VEP izmeklējumā un analizējot pagarinātas P 100 latences un MRI izmaiņu biežumu pacientiem ar MS, konstatēts, ka 21 gadījumā (21\% no ar MRI izmeklēto acu skaita) ar MS slimiem pacientiem, kam ir redzes nerva bojājums, MRI atrod arī pagarinātu P 100 latenci. Turklāt, balstoties uz Pīrsona hī kvadrāta statistisko testu, secināts, ka starp redzes nerva demielinizāciju MRI un P 100 latenci pastāv statistiski ticama korelācija ( $p<0,01)$, bet efekta lielums ir vidējs $(\varphi=0,30)$.

Veicot MRI izmeklējumu galvas smadzenēm un saskaitot demielinizējošus perēkḷus, konstatēts, ka pacientiem ar samazinātu RNFLT biezumu perēkḷu skaits galvas smadzenēs ir statistiski ticami lielāks, nekā tas ir pacientiem ar normālu RNFLT biezumu ( $\mathrm{p}<0,001)$. Turklāt minētās sakarības efekta lielums, izmantojot ROC līkni, ir statistiski labs $(\mathrm{AUC}=0,80 ; \mathrm{p}<0,01)$.

Balstoties uz Manna-Vitnija testu un atsevišḳi analizējot tikai to demielinizējošo perēkḷu skaitu, kuri skar redzes ceḷus galvas smadzenēs (chiasma opticum, tractus opticus un radiatio optica rajonos), konstatēts, ka pacientiem ar samazinātu RNFLT biezumu šādu perēkḷu skaits ir lielāks nekā 
pacientiem, kuriem RNFLT biezums ir normas robežās ( $\mathrm{p}<0,001)$. Tomēr efekta lielums ir statistiski vājš $(\mathrm{AUC}=0,67 ; \mathrm{p}<0,01)$.

Analizējot galvas smadzeṇu atrofiju MRI izmeklējumā, konstatēts, ka 28 gadījumos (28\% no ar MRI izmeklēto acu skaita) pacientiem, kuriem šo atrofiju konstatē, atrod ar̄̄ samazinātu RNFLT biezumu. Turklāt tikai 11 gadījumos pacientiem bez atrofijas pazīmēm MRI tika novērots samazināts RNFLT biezums. Izvērtējot galvas smadzeṇu atrofijas un samazināta RNFLT biezuma savstarpēju saistību, secināts, ka starp šiem parametriem pastāv statistiski ticama sakarība $(\mathrm{p}<0,001)$ un iedarbības statistiskais novērtējums ir gandrīz liels $(\varphi=0,44)$.

Analizējot aktīvu, kontrastvielu krājošu perēkḷu esamību un skaitu, konstatēts, ka tie samazinātu RNFLT biezumu neietekmē $(p=0,64)$.

Kopumā izvērtējot visus RNFLT biezumu ietekmējošus faktorus un balstoties uz loǵistiskās regresijas analīzes metodi, tika izstrādāts modelis, ar kura palīdzību iespējams prognozēt samazinātu RNFLT biezumu. Loǵistiskā modeḷa novērtēšanas kvalitātes koeficients (Nagelkerkes $R$ ) ir $28 \%$.

Analizējot izredžu attiecības no aprēḳinātā loǵistiskās regresijas modeḷa, secināts, ka indivīdiem, kuriem N 75/P 100 amplitūda ir samazināta, izredzes būt samazinātam RNFLT biezumam ir 4,25 reizes lielākas nekā pacientiem ar normālu VEP amplitūdu. Savukārt indivīdiem, kuriem ir pagarināta P 100 latence, izredzes būt samazinātam RNFLT biezumam ir 6,81 reizi lielākas nekā pacientiem, kuriem VEP amplitūda ir normas robežās.

Izveidotajā modelī tika iekḷauti tikai savstarpēji neatkarīgi statistiski ticami RNFLT biezumu ietekmējoši faktori. Tika iegūts šāds vienādojums:

Logit (samazinātam RNFLT biezumam) $=-3,09+1,44 \times \mathrm{N} 75 / \mathrm{P} 100$ amplitūda $+1,92 \times \mathrm{P} 100$ latence

Veicot matemātiskas transformācijas, katrā konkrētā gadījumā ir iespējams aprēḳināt precīzu samazināta RNFLT biezuma varbūtību. 
Loǵistiskās regresijas modelī tika ievietotas arī citas pazīmes, kuras varētu ietekmēt samazinātu RNFLT biezumu, piemēram, vecums, EDSS, redzes asums, krāsu redzes, redzes lauku izmaiņas, kā arī RNN epizode anamnēzē, taču ar šīm pazīmēm statistiski ticamu samazināta RNFL biezuma prognozēšanas modeli iegūt neizdevās. 


\section{DISKUSIJA}

\subsection{Funkcionālas aferento redzes ceḷu izmaiṇas}

Analizējot redzes asumu kā vienkārši diagnosticējamu funkcionālu aferento redzes ceḷu parametru, pētījumā konstatējām, ka lielai daḷai pacientu ar MS (72\%) bija būtiski redzes asuma traucējumi. Ar MS slimu pacientu grupā pēc pārciestas RNN epizodes vidējais korig̣ētais redzes asums bija salīdzinoši labs $-0,93$, taču pilnīga redzes korekcija $(\geq 1,0)$ bija iespējama tikai nelielai daḷai pacientu (10\%). Šajā pacientu grupā tika iekḷauti tikai pacienti ar unilaterālu RNN, taču arī otrajās - RNN tieši neskartajās - acīs tikai 6 gadījumos (18\% no $\mathrm{RNN}(-)$ acīm) bija iespējama pilnīga redzes asuma korekcija, kas norāda uz būtisku redzes disfunkciju abām acīm.

Analizējot pacientu ar MS grupu bez RNN anamnēzēe, konstatējām, ka, neraugoties uz RNN klīnisku neesamību, tikai 35\% gadījumu šajā grupā bija iespējams redzes asums $\geq 1$. Lielākajai daļai šīs grupas pacientu redzes asumu neizdevās pilnībā korig̣ēt, kaut arī RNN klīnisko pazīmju nekad nebija bijis. Šādi rezultāti norāda uz subklīniski noritošu redzes disfunkciju pacientiem ar MS.

Literatūrā tiek uzsvērts, ka daudziem ar MS slimiem pacientiem novēro ievērojamus redzes traucējumus, pat gadījumos, kad ir saglabāts redzes asums 1,0 (Fiona Costello, 2013; Fisher et al., 2006; Sakai et al., 2011). Vairākos pētījumos pierādīts, ka pacientiem ar MS, salīdzinot ar veseliem indivīdiem, redzes funkciju būtiski ietekmē samazināts attēla kontrasts un pacientu izmeklēšanai vēlams izmantot zema kontrasta burtu asuma pārbaudi, taču tā nav iekḷauta ikdienas praksē izmantojamā EDSS kopvērtējumā (Balcer and Frohman, 2010; Bermel and Balcer, 2013). Šis tests identificē grūtības uztvert samazināta kontrasta attēlus arī pacientiem bez iepriekšējas RNN epizodes un norāda uz traucētu dzīves kvalitāti un apgrūtinātām ikdienas darbībām: lasī̌sanu, 
cilvēku atpazī̌šnu un auto vadīšanu (Fiona Costello, 2013; Sakai et al., 2011). Turklāt literatūrā minēts, ka, neraugoties uz redzes asumu 1,0, acīs, kurās bijusi RNN epizode, zema kontrasta redze ir sliktāka nekā acīs, kurās RNN nav bijis (Frohman, Frohman, Zee, McColl, and Galetta, 2005). Lai gan šobrīd tiek uzskatīts, ka redzes asums ir salīdzinoši maz informatīvs rādītājs aferentās redzes sistēmas funkcijas izvērtēšanai, papildus veicot zema kontrasta burtu pārbaudi, veiktajā pētījumā tiktu diagnosticēti vēl vairāki redzes disfunkcijas gadījumi.

Redzes ceḷu aksonāli demielinizējoša procesa funkcionālai diagnostikai pētījumā tika izmantoti vidējie P 100 latences un N 75/P 100 amplitūdas mērījumi ar VEP metodi. Konstatējām, ka būtiski zemāka vidējā N 75/P 100 amplitūda bija vērojama ar MS slimu pacientu grupā ar RNN anamnēzē, turklāt tieši RNN skartajās acīs vidējā amplitūda bija par 6,35 mkV mazāka, salīdzinot ar kontroles grupu $(\mathrm{p}<0,001)$, kas norāda uz aksonālās integritātes traucējumiem pēc RNN epizodes, iespējams, iepriekšējas demielinizācijas dēḷ. Tomēr šajā grupā arī otrajās - RNN tieši neskartajās - acīs 51\% gadījumu tika konstatêta patoloǵiski samazināta vidējā N 75/P 100 amplitūda, un šajā gadījumā jādomā par citu, ar akūtu demielinizācijas epizodi nesaistītu, aksonālā audu slāṇa funkcionālu bojājumu.

Līdzīgas aksonālu audu funkcijas izmaiņas vērojamas arī pacientiem ar MS grupā bez RNN epizodes anamnēzēe Šajā grupā pacientiem vidējā N 75/P 100 amplitūda bija statistiski ticami par 4,65 mkV zemāka nekā kontroles grupas indivīdiem. Turklāt, nosakot precīzu N 75/P 100 amplitūdas robežvērtību, šajā pacientu grupā pazemināta amplitūda tika konstatēta lielākajai daḷai $-63 \%$ pacientu.

Atsevišḳi analizējot vidējo P 100 latenci, tika iegūti līdzīgi rezultāti. Izteiktākais vidējās P 100 latences pagarinājums vērojams ar MS slimu pacientu grupā ar pārciestu RNN. RNN skartajās acīs tā ir 126,0 ms, kas ir vidēji par 24,19 ms garāka nekā kontroles grupai. Taču arī pacientu grupā bez RNN anamnēzē vidējā P 100 latence bija par 14,92 ms garāka, salīdzinot ar kontroles 
grupu. Turklāt, līdzīgi kā subklīniska aksonāla bojājuma gadījumā, 60\% pacientu bez RNN klīniskajām pazīmēm anamnēzē konstatēja subklīnisku P 100 latences pagarinājumu.

Lai arī redzes izraisīto potenciālu izmeklējums sākotnēji tika minēts kā papildu kritērijs primāri progresējošas MS diagnozes noteikšanai (McDonald et al., 2001; Polman et al., 2005), tomēr 2010. gadā revidētajos Makdonalda kritērijos tas netika atkārtoti iekḷauts (Polman et al., 2011) un VEP loma MS diagnostikā ir mazinājusies. Ir veikti nedaudzi pētījumi par VEP nozīmi pacientu ar MS subklīniska redzes nerva bojājuma diagnostikai. No eksperimentāla autoimūna RNN modẹ̦a zināms, ka VEP amplitūdas samazinājums norāda uz aksonālo audu bojājumu, bet latences pagarinājums ir agrīna demielinizācijas pazīme (You et al., 2011). Raugoties no šī aspekta, īpaši nozīmīgi varētu būt pētījumi, kuros veikta VEP amplitūdas izpēte pacientiem, kuriem aksonāls bojājums nevarēja rasties sekundāri redzes nerva demielinizācijas dēl, tātad pacientiem bez klīniskas RNN anamnēzes.

Mūsu pētījuma rezultāti pierāda, ka VEP izmeklējums var sniegt papildu informāciju par redzes ceḷu integritāti, īpaši gadījumos, kad nav vērojamas klīniski noteiktas RNN pazīmes. Turklāt tas var apstiprināt redzes sistēmas iesaisti klīniski neskaidrās situācijās un gadījumos, kad pacients kognitīvu traucējumu dēḷ savu anamnēzi nevar skaidri definēt. Izmainīti VEP rādītāji klīniski neskartajās acīs sniedz informāciju par subklīniskiem perēkḷiem redzes ceḷos, kas var palīdzēt identificēt perēkḷu disemināciju telpā, sniedzot papildu kritērijus MS diagnozei (Sakai et al., 2011), tomēr nav skaidrs, vai šie bojājumi nav alternatīva, ar iekaisuma aktivitāti nesaistīta procesa sekas.

Pēdējo gadu literatūrā apskatīta multifokālu VEP metode, kura pieḷauj vairāku redzes lauku daḷu vienlaicīgu stimulāciju un atsevišķu mazu aksonu grupu izpēti, veicot topogrāfisku analīzi (Klistorner et al., 2009). Nesen publicēts pētījums, kurā, izmantojot multifokālu VEP analīzi, pierādīta hipotēze 
par retrogenikulāru demielinizāciju RNN neskartajās acīs (Alshowaeir et al., 2014). Pašreiz multifokāla VEP tehnika Latvijā nav pieejama.

Pētījumā funkcionāla redzes ceḷu veseluma izpētei izmantojām arī krāsu redzes izpēti. Mūsu pētījuma rezultāti parādīja, ka krāsu redzi ietekmē RNN esamība anamnēzē, tā attīstās 19\% gadījumu pēc RNN epizodes. Tomēr arī 14\% pacientu bez iepriekšèjas RNN anamnēzē krāsu redze bija traucēta. Tas norāda, ka krāsu redzes traucējumi var veidoties bez akūta redzes nerva iekaisuma anamnēzē. Līdzīgi rezultāti publicēti nesenā pētījumā, kur konstatēts, ka krāsu redze bija izmainīta 19\% acu bez iepriekšēja RNN, turklāt šiem pacientiem, veicot longitudinālu novērojumu gada laikā, attīstījās nopietnāki citu funkciju traucējumi un straujāk progresēja invaliditāte, salīdzinot ar pacientiem, kuriem krāsu redze nebija traucēta (Martinez-Lapiscina et al., 2014). Tātad, iespējams, krāsu redzes izmaiņām ir arī prognostiska nozīme.

Pārliecinošu funkcionālu redzes defektu novērojām, veicot redzes lauku izpēti pacientiem bez RNN anamnēzē. Mūsu pētījumā paracentrālas skotomas attīstījušās pat $64 \%$ šīs grupas pacientu. Tomēr salīdzinoši biežāk $(85 \%$ gadījumu) redzes lauku defekts veidojās pētījumā iekḷautajiem pacientiem ar RNN anamnēzē acīs ar pārciestu RNN. Kaut arī redzes lauku ierobežojumi ir viena no raksturīgākajām RNN klīniskajām pazīmēm un saslimšanas sākumā attīstās gandrīz visiem pacientiem (Balcer, 2006; Fiona Costello, 2013), mūsu pētījuma rezultāti liek domāt, ka redzes lauku defekts rodas arī neatkarīgi no RNN klīniskajām pazīmēm. Līdzīga tendence konstatēta arī longitudinālā pētījumā, kurā analizētas RNN skartās acis 15 gadus pēc RNN epizodes un tajās redzes lauka defekts saglabājies 39,5\% gadījumu, taču šiem pacientiem arī otrajās - RNN neskartajās - acīs šis defekts attīstījies 26,3\% gadījumu (Keltner et al., 2010). Šajā pētījumā, līdzīgi kā mūsu novērojumos, konstatēts, ka biežākais redzes lauku defekta veids ir parciāli bojājumi, tostarp paracentrālas skotomas. Lai arī redzes lauku defekti pārliecinoši norāda uz funkcionālu aferento redzes ceḷu veseluma bojājumu, kas turklāt, izmantojot automatizēto 
perimetriju, ir viegli diagnosticējams un interpretējams, veicot šo izmeklējumu, jāṇem vērā subjektīvais faktors. Pacientiem ar MS raksturīgais nogurums un uzmanības traucējumi var radīt viltus pozitīvus traucējumus redzes laukos.

\subsection{Strukturālas aferento redzes ceḷu izmaiṇas}

Kopš oftalmoskopa ieviešanas visbiežāk redzes nerva struktūra un bojājuma pazīmes tiek analizēti tieši, fundus oculi apskatē. Redzes nerva neirīta akūtā fāzē vienai trešdaḷai pacientu vērojama redzes nerva diska tūska, t. i., papillīts, kuram seko redzes nerva diska nobālējums. Divām trešdaḷām pacientu akūtu izmaiņu fundus oculi apskatē nav, jo bojājums attīstījies redzes nerva retrobulbārajā daḷā (Balcer, 2006; Voss et al., 2011). Mūsu pētījumā, analizējot strukturālas makroskopiskas izmaiņas fundus oculi apskatē, konstatējām, ka biežāk redzes nerva diska nobālējumu temporālajā daḷā atrod ar MS slimiem pacientiem grupā ar iepriekš pārciestu RNN, tomēr to novēroja tikai $24 \%$ no RNN skartajām acīm. Arī 15\% pacientu, kuriem nebija RNN anamnēzē, novēroja šādas izmaiņas. Balstoties uz šiem rezultātiem, jāsecina, ka redzes nerva diska temporālu nobālējumu būtiski neietekmē RNN esamība anamnēzē un tā attīistība ir saistīta ar citiem, iespējams, neirodeǵeneratīviem procesiem. Šo iespējamību apstiprina arī mūsu iegūtie dati par samazinata RNFLT biezuma saistību ar redzes nerva diska temporālu nobālējumu abās pacientu grupās.

Analizējot literatūru, jāsecina, ka redzes nerva diska temporāla nobālējuma etioloǵija nav pilnībā noskaidrota. Tiek uzskatīts, ka tas ir saistīts ar aksonālu deǵenerāciju un nervu šḳiedru slāṇa biezuma un arhitektūras bojājumu (Neuro-Ophthalmology Review Manual (7th Edition), 2012). Temporāla redzes nerva diska nobālējuma lokalizācija norāda uz izteiktākām izmaiņām temporālajā rajonā, t. i., rajonā, kur nervu šķiedras virzās uz makulu un veido papillomakulāro kūlīti. Jādomā, ka arī pacientiem bez akūtas iekaisuma epizodes attīstās šāds bojājums, tomēr fundus oculi apskates rezultāti jāanalizēe 
piesardzīgi, jo, lai arī izmeklējumus visiem pacientiem mūsu pētījumā veica viens oftalmologs, redzes nerva diska nobālējums ir subjektīvi interpretējams rādītājs.

Izteiktāku temporālā rajona iesaisti mūsu pētījumā apstiprina ar optisko koherences tomogrāfiju (OCT) izmeklējumu veikti mikroskopiski tīklenes nervu šķiedru slāṇa (RNFL) biezuma mērījumi. Vadoties pēc mūsu rezultātiem, RNFL biezums tieši temporālajā segmentā (RNFLT) bija ar vislielākajām atšķirībām starp pētījuma grupām, un šādi rezultāti iegūti arī citos pētījumos (Fjeldstad, Bemben, and Pardo, 2011; Gelfand et al., 2012; Klistorner et al., 2013; Tatrai et al., 2012; Wang et al., 2010). Tomēr dažu autoru pētījumos ar MS slimo pacientu acīs tika novērots difūzs RNFL biezuma samazinājums visos kvadrantos (Serbecic et al., 2010; Urano et al., 2011). Turklāt veikti arī longitudināli pētījumi, kuros šis samazinājums ir progresējošs un izteiktāks augšējā kvadrantā (Herrero et al., 2012). Daži autori izvirzījuši pieṇēmumu, ka temporāls RNFL biezuma samazinājums vērojams pacientiem pēc RNN epizodes, bet gadījumos, ja RNN nav bijis, RNFL biezums samazinās difūzi (Bock et al., 2010), taču mūsu pētījumā šì hipotēze netika apstiprināta.

Mūsu veiktajā pētījumā visplānākais RNFT biezums bija RNN skartajās acīs (vidēji 56,44 mkm), taču arī acīs bez RNN anamnēzē tas bija statistiski ticami ievērojami plānāks (vidēji 62,12 mkm) par kontroles grupu (vidēji $70,92 \mathrm{mkm}$ ). Šādu subklīnisku RNFLT bojājumu novērojušas vairākas pētnieku grupas (Fjeldstad et al., 2011; Garcia-Martin et al., 2010; Parisi et al., 1999; Pueyo et al., 2008; Quelly, Cheng, Laron, Schiffman, and Tang, 2010; Zaveri et al., 2008), un literatūrā izteikta hipotēze, ka RNFLT biezuma samazinājumu RNN skartajās acīs radījusi retrogrāda aksonāla deǵenerācija kā redzes nerva retrobulbāras demielinizācijas sekas. Līdzīgi rezultāti publicēti nesen veiktā metaanalīzē, kurā apkopoti 14 pêtījumu dati un aprēḳināts, ka, salīdzinot RNN skartās acis ar kontroles grupas indivīdiem, vidējais RNFL biezuma 
samazinājums ir $20 \mathrm{mkm}$, bet RNN neskartajās acīs RNFL biezums ir vidēji par 7 mkm plānāks, salīdzinot ar kontroles grupu (Petzold et al., 2010).

Lai izmaiṇas aferentajā redzes sistēmā varētu aplūkot kā MS raksturojošu parametru, mūsu pētījumā bija būtiski noskaidrot šo izmaiņu un citu slimību raksturojošo rādītāju savstarpējo saistību. Šāds aspekts ir klīniski nozīmīgs, un literatūras dati par to ir l̦oti atšķirīgi.

Analizējot slimības ilguma ietekmi uz tīklenes nervu šķiedru slāņa biezumu, secinājām, ka pacientu grupai ar MS un RNN anamnēzē starp RNFLT biezumu un slimības ilgumu mēnešos pastāv statistiski ticama korelācija, tātad RNFLT biezums pēc akūtas RNN epizodes turpina samazināties. Veikts pētījums, kurā apstiprināta slimības ilguma ietekme uz RNFL biezumu un aprēkināts, ka tas turpina samazināties par 3,7 mkm gadā pēc RNN epizodes ( $F$. Costello et al., 2006).

Tomēr publicēti arī pêtījumi, kuros apgalvots, ka RNFL biezumu slimības ilgums neietekmē (Serbecic et al., 2010). Eksperimentāli modeļi pierāda, ka pēc pilnīga redzes nerva šķērsbojājuma RNFL biezuma samazinājums attīstās 2 mēnešu laikā (Fiona Costello, 2013). Savukārt longitudinālos pētījumos noskaidrots, ka RNFL biezums turpina samazināties 6 mēnešu laikā pēc simptomu sākuma un stabilizējas 7-12 mēnešu laikā (F. Costello et al., 2008). Mūsu pētījumā arī ar MS slimo pacientu grupā bez iepriekš pārciesta RNN pastāv korelācija starp RNFLT biezumu un slimības ilgumu. Literatūrā publicēti rezultāti liecina, ka ar MS slimiem pacientiem bez akūtas RNN epizodes RNFL biezuma samazinājums norit straujāk, nekā tas ir normāla novecošanas procesa rezultātā (Talman et al., 2010), un tas samazinās vidēji par $2 \mathrm{mkm}$ gadā (Talman et al., 2010). Papildu neskaidrības rada apstāklis, ka publicētajos pētījumos izmantotas dažādas OCT tehnikas (Heidelberg Spectralis un Cirrus HD-OCT), tāpēc, interpretējot šos rezultātus, jāievēro piesardzība. Jebkurā gadījumā acīs bez akūtas RNN epizodes anamnēzē RNFLT bojājumu nevarēja radīt akūta demielinizācija, un tas uzskatāms par primāru notikumu, kas radies citu 
mehānismu dēḷ. Tomēr arī šāds rezultātu skaidrojums nav nepārprotams, jo iespējams arī subklīniski noritošs demielinizācijas process, kuru pacients nav konstatējis. Patlaban nav skaidrs, vai tiešām klīniski noteikts redzes nerva iekaisums rada RNFL biezuma samazinājumu, jo aprakstīts, ka pacientiem ar primāri progresējošu MS bez RNN epizodēm vēro pat izteiktāku RNFL biezuma samazinājumu nekā pacientiem ar recidivējoši remitējošu MS pēc atkārtotām RNN epizodēm (Oberwahrenbrock et al., 2012).

N̦emot vērā šos apsvērumus un veicot redzes sistēmas izmeklējumus, mēs nevaram droši pateikt, vai tīklenes bojājumam ir primārs raksturs vai arī tas veidojas sekundāri demielinizācijai. Šajā aspektā ir daudz neskaidrību, taču veikto izmeklējumu rezultāti ḷauj apšaubīt agrāk izvirzīto teoriju, ka MS ir primāri demielinizējoša patoloǵija un tikai sekundāri demielinizācijai rodas aksonālo audu bojājums.

Svarīgu informāciju par aferento redzes ceḷu patoloǵijas klīnisko nozīmi sniedz RNFLT biezuma izmaiņu saistība ar pacienta vispārējo neiroloǵisko stāvokli un invaliditāti. Mūsu pētījumā RNFLT biezums abām pacientu ar MS grupām statistiski ticami korelē ar EDSS kopvērtējumu, tātad, samazinoties RNFLT biezumam, palielinās invaliditātes līmenis un neiroloğiskie traucējumi funkcionālajās sistēmās. Tomēr jāṇem vērā, ka EDSS kopvērtējuma aprēķinos tiek iekḷauta arī redzes sistēma. Pacientam ar izteiktiem redzes traucējumiem būs lielāks EDSS kopvērtējuma skaitlis, taču, ja citās sistēmās nav būtisku izmaiṇu, EDSS kopvērtējums nevar būt lielāks par 4.

RNFL satur tikai nemielinizētus aksonus, un zināms, ka tieši aksonāla patologija tiek saistīta ar invaliditātes smagumu un neatgriezenisku progresiju post mortem pētījumos (Trapp et al., 1998), kas norāda uz nepieciešamību papildus analizēt tieši šo audu slāni un faktorus, kas to ietekmē. N̦emot vērā iegūto korelāciju, var tikt izvirzīts pieņēmums, ka tīklenes aksonālā slāṇa izmaiņas reprezentē tās pašas MS radītā bojājuma izpausmes, kas novērojamas difūzi citviet CNS. Tomēr, analizējot literatūru, tika konstatēts, ka dati nav 
nepārprotami. Daži autori apraksta mūsu rezultātiem līdzīgu negatīvu RNFLT biezuma un EDSS kopvērtējuma korelāciju (Grazioli et al., 2008; Tatrai et al., 2012; Toledo et al., 2008), taču dažu citu autoru pētījumi šādu saistību neapstiprina (Moghaddasi et al., 2011; Pueyo et al., 2008). Dažos pētījumos izvirzīta hipotēze, ka EDSS korelē ar RNFLT biezumu tikai pacientiem bez RNN anamnēzē (Albrecht, Frohlich, Hartung, Kieseier, and Methner, 2007). Pētīta arī RNFL biezuma saistība ar EDSS progresiju un pierādīts, ka pacientiem bez iepriekšēja RNN RNFL atrofija korelē ar straujāku slimības progresiju (Sepulcre et al., 2007). Šī jautājuma plašākai izpētei turpmāko pētījumu mērḳa populācija varētu būt pacienti ar MS bez RNN anamnēzēe, tomēr jāņem vērā, ka EDSS kopvērtējums ir maz informatīvs slimības sākumā un pacientiem ar klīniski izolētu sindromu.

Lai arī EDSS kopvērtējums ietver redzes asuma mērījumus, mūsu pētījumā papildus meklējām arī RNFL biezuma saistību ar redzes asuma funkciju. Tika secināts, ka ar MS slimiem pacientiem acīs, kurās nav bijusi RNN epizode, šie faktori savstarpēji statistiski ticami korelē. Tomēr, balstoties uz mūsu pētījuma rezultātiem, RNN skartajās acīs starp RNFLT biezumu un koriğētu redzes asumu statistiski ticama korelācija netika pierādīta. Iespējams, šāds rezultāts radies, jo redzes asuma mērījumiem izmantojām Snellena tabulu, kuru lieto EDSS kopvērtējuma noteikšanai. Literatūrā aprakstīts, ka RNFL biezuma samazinājums par $1 \mathrm{mkm}$ paredz redzes asuma samazinājumu par 0,01 log MAR, izmantojot ETDRS tabulu (Trip et al., 2005). Lielākajā daḷā publicēto pētījumu RNFLT biezums korelē ar redzes asumu, kas noteikts ar ETDRS tabulām (Wang et al., 2010), kas tiek rekomendētas kā "zelta standarts" MS medikamentu klīniskajos pētījumos (Fiona Costello, 2013). Turklāt literatūrā aprakstīts, ka tīklenes nervu šķiedru slāṇa izmaiņas acīs pēc RNN būtiski ietekmē ar zema kontrasta burtu testu noteikto redzes asumu (Fisher et al., 2006; Merle et al., 2010; Talman et al., 2010). 
Analizējot krāsu redzes izmaiņas, tika konstatēts, ka visiem ar MS slimajiem pacientiem starp samazinātu RNFLT biezumu un izmainītu krāsu redzi pastāv statistiski ticama sakarība. Veikts pētījums, kurā aprakstīta izmainītas krāsu redzes labāka korelācija ar samazinātu RNFL biezumu, nekā tā ir redzes asumam (Villoslada et al., 2012). Mūsu pētījumā kopumā tikai 10\% no visiem ar MS slimajiem pacientiem novēroja vienlaicīgu RNFLT biezuma samazinājumu un krāsu redzes traucējumus. Literatūrā minēts, ka, iespējams, pacientiem ar persistējošiem krāsu redzes traucējumiem MS dinamikā progresēs straujāk, salīdzinot ap pacientiem, kuriem krāsu redze nav traucēta (MartinezLapiscina et al., 2014).

Mūsu pētījumā arī izmaiņas redzes lauku perimetrijā ir statistiski ticami saistītas ar samazinātu RNFLT biezumu, kaut gan 40\% pacientu novērojams redzes lauku defekts un neizmainīts RNFLT biezums. Literatūras datos minēta samazināta RNFL biezuma ietekme uz neatgriezeniska redzes lauka defekta prognozi; lielākajai daḷai pacientu redzes lauka defekts attīstìjās 3-6 mēnešus pēc RNN epizodes un gadījumos, kad RNFL biezums bija samazināts zem $75 \mathrm{mkm}$, redzes lauka defekts bija neatgriezenisks (F. Costello et al., 2008).

Līdzīgi iepriekš veiktajiem pētījumiem (Fisher et al., 2006; Klistorner et al., 2008; Naismith et al., 2009; Talman et al., 2010; Trip et al., 2005) mūsu rezultāti apstiprina, ka gan VEP, gan OCT mērījumi var tikt izmantoti subklīniska RNN noteikšanai RNN neskartajās acīs. Vadoties pēc mūsu pētījuma rezultātiem, pastāv vidēji stipra korelācija starp RNFLT biezumu un vidējo N 75/P 100 amplitūdu, kā arī vidējo P 100 latenci gan acīs pēc pārciesta RNN, gan RNN neskartajās acīs. Literatūras dati ir līdzīgi (Di Maggio et al., 2014; Naismith et al., 2009), tomēr daži autori apstiprina RNFLT biezuma izolētu saistību ar P 100 latenci (Fatehi et al., 2012), bet citi ar VEP amplitūdu (Trip et al., 2005). N̦emot vērā, ka tiek aplūkoti dažādi bojājuma aspekti (strukturāls un funkcionāls), iespējams rekomendēt veikt abus šos izmeklējumus pat pacientiem bez sūdzībām par redzes traucējumiem, īpaši klīniski neskaidrās 
situācijās, kad RNN simptomi ir vāji izteikti vai pacients nevar tos adekvāti definēt.

Mūsu pētījumā konstatējām, ka OCT metode diagnosticē gandrīz divas reizes mazāk redzes nerva bojājuma gadījumus, salīdzinot ar VEP, un tikai 4\% bija vienlaicīgi novēroti normāli VEP rezultāti, bet samazināts RNFLT biezums. Analizējot ROC līknes parametrus, piemērotākais diagnostiskais tests klīniska RNN apstiprināšanai ir P 100 latence, kā nākamais ir N 75/P 100 amplitūda, un salīdzinoši vājākā metode ir RNFLT biezuma noteikšana. RNFLT biezums ir parametrs ar salīdzinoši zemāku sensitivitāti, taču ḷoti augstu specifiskumu un pozitīivu paredzamo vērtību, kas skaidrojama ar labi izveidotu normatīvo datubāzi. Viens no iespējamajiem skaidrojumiem zemajai RNFLT biezuma sensitivitātei ir fakts, ka šis tests norāda tikai uz aferento redzes ceḷu sākuma dalı, bet VEP norāda uz redzes ceḷu veselumu no tīklenes līdz pat redzes garozai. Turklāt jāṇem vērā, ka situācijās pēc RNN epizodes RNFL biezuma samazinājums veidojas sekundāri demielinizācijai redzes nervā, tas notiek retrogrādi, un šis bojājums var būt nepilnīgs. Papildus kḷūdaini lielāku RNFL biezumu varēja radīt aksonālu audu aizvietošana ar gliāliem audiem. Lai uzlabotu OCT sensitivitāti, nesen daži autori (Davies et al., 2011; Seigo et al., 2012; Walter et al., 2012) piedāvāja veikt atsevišķus ganglija šūnu slāņa un iekšèjā retikulārā slāṇa mērījumus, kas varētu vēl precīzāk norādīt uz aksonālu bojājumu, jo šīs struktūras nesatur papildus glijas audus un asinsvadus (Hood, Salant, Arthur, Ritch, and Liebmann, 2010). Tomēr jāṇem vērā, ka ganglija šūnu slāņa un iekšējā retikulārā slāņa mērījumi pašreiz ir iespējami tikai manuāli, kas ir laikietilp̄̄gs process un nav pielietojams klīniskajā praksē. Literatūrā nav pieejami dati ar precīziem VEP un OCT sensitivitātes mērījumiem, taču arī publikācijās ar konstatēto gadījumu skaitu VEP metode atklāja patologiju biežāk nekā OCT (Di Maggio et al., 2014; Naismith et al., 2009). Tātad, ja apstākḷu dēl iespējams veikt tikai vienu metodi, priekšroka dodama redzes izraisīto potenciālu izmeklējumam, tomēr abu metožu kombinācija palielina iespējas diagnosticēt 
redzes nerva bojājumu. Turklāt, balstoties uz mūsu pētījumā izstrādāto modeli, samazinātu RNFLT biezumu iespējams paredzēt, izmantojot VEP parametrus.

Analizējot citas pieejamās metodes redzes nerva struktūras izpētei, konstatējām, ka redzes nerva diska nobālējums fundus oculi korelē ar samazinātu RNFLT biezumu, īpaši gadījumos pēc RNN klīniskās epizodes.

Lai arī magnētiskās rezonanses izmeklējums netika veikts visiem ar MS slimajiem pacientiem, gandrīz visiem pacientiem (96\% no RNN (+) acīm), kuriem bijusi klīniska RNN epizode, vērojama redzes nerva demielinizācija MRI. Tomēr tikai 15\% gadījumu vienlaikus ar demielinizējošām redzes nerva izmain̄ām MRI izmeklējumā bija novērots arī samazināts RNFLT biezums, bet 24\% MRI redzes nerva bojājumu neuzrādīja un bija samazināts RNFLT biezums. Mūsu pētījuma rezultāti apstiprina, ka starp redzes nerva demielinizāciju MRI un samazinātu RNFLT biezumu statistiski ticama korelācija nepastāv. Līdzīgi šādu korelāciju neizdevās pierādīt arī starp redzes nerva izmaiņām MRI un samazinātu VEP amplitūdu. Tomēr statistiski ticama korelācija tika iegūta starp redzes nerva demielinizāciju MRI un P 100 latenci. Domājams, š̄ saistība apstiprina faktu, ka P 100 latences izmaiņas primāri saistītas ar mielīna apvalka bojājumu redzes nervā.

Būtiski rezultāti iegūti, saskaitot demielinizējošus perēkḷus MRI izmeklējumā galvas smadzenēm un konstatējot, ka pacientiem ar samazinātu RNFLT biezumu perēkḷu skaits ir statistiski ticami lielāks, nekā tas ir pacientiem ar normālu RNFLT biezumu. Turklāt arī pacientiem ar samazinātu RNFLT biezumu perēkḷu skaits, kuri skar redzes ceḷus galvas smadzenēs, ir lielāks nekā pacientiem, kuriem RNFLT biezums ir normas robežās. Savukārt aktīvu, kontrastvielu krājošu perēkḷu skaits RNFLT biezumu neietekmē.

Svarīgus secinājumus iespējams izdarīt pēc iegūtiem rezultātiem par galvas smadzeņu atrofiju MRI izmeklējumā. Lai arī Latvijā pašreiz netiek veikti precīzi galvas smadzeņu atrofijas mērījumi, radiologa novērotas atrofiskas pazīmes galvas smadzenēs statistiski ticami korelē ar samazinātu RNFLT 
biezumu. Veicot precīzus smadzeņu atrofijas mērījumus, Gordona-Lipkina u. c. autoru darbā (Gordon-Lipkin et al., 2007) samazināta smadzeņu parenhimālā frakcija korelēja ar samazinātu RNFL biezumu. Tāpēc viņi izvirzīja hipotēzi, ka atrofiskas RNFL izmaiņas atspoguḷo atrofiskas izmaiņas galvas smadzenēs. Nesen publicēti dati, ka samazināts RNFL biezums saistīts arī ar thalamus atrofiju (Zivadinov et al., 2014), kā arī pierādīts, ka galvas smadzeņu atrofija vienlaikus ar RNFLT biezumu korelē arī ar neatgriezenisku invaliditāti (AbaloLojo et al., 2014) un nogurumu (Cruz Gomez, Ventura Campos, Belenguer, Avila, and Forn, 2013). Zināms, ka ne tikai atrofiskas izmaiṇas, bet arī perēkḷu skaits galvas smadzenēs korelē ar invaliditātes līmeni (Popescu et al., 2013), un šie rādītāji var tikt izmantoti slimības gaitas prognozēšanai. Šiem novērojumiem ir ḷoti būtiska nozīme. Izteikts pieņēmums, ka RNFL atrofija ir centrālās nervu sistēmas atrofijas pazīme, un, veicot neinvazīvus un ātrus acu izmeklējumus, iespējams sekot slimības gaitai un izmaiṇām dažādās situācijās, piemēram, izvērtēt terapijas efektivitāti, lietojot neiroprotektīvus medikamentus. Daži autori arī izteikuši pieņēmumu, ka agrīna RNFL samazināšanās var paredzēt straujāku smadzeṇu atrofijas attīstību (Chan, 2012), taču tas vēl nav apstiprināts longitudinālos pētījumos. Turklāt, pētot pacientus ar klīniski izolēto sindromu, RNFL biezuma mērījumi neietekmēja turpmāko MS attīstības risku (Outteryck et al., 2009).

\subsection{Turpmāko pētījumu virzieni}

Aferento redzes ceḷu modelis paver iespējas plašāk izpētīt slimības mehānismus, kas rada neiroloǵiskos traucējumus un invaliditāti pacientiem ar MS. Monitorējot akūtas un hroniskas sekas klīniskai RNN epizodei, iespējams iegūt informāciju par faktoriem, kas ietekmē paasinājuma procesu, kā arī modelēt funkcionāli strukturālu atjaunošanos pēc paasinājuma, kas, iespējams, 
norit arī citās CNS dạ̦ās. Veicot longitudinālus novērojumus un izvēloties par pētījumu objektiem pacientus bez RNN epizodes anamnēzē, būtu iespējams iegūt svarīgu informāciju par to, vai un kā aksonāls un neironāls bojājums norit neatkarīgi no iekaisuma procesa aferentajos redzes ceḷos, tātad arī CNS. Īpaši mērḳtiecīga un nozīmīga varētu būt neiroprotektīvu medikamentu izpēte š̄is grupas pacientiem, aferentajos redzes ceḷos novērojot dinamiskas neiroprotektīvas, neiroreǵeneratīvas un remielinizējošas izmaiņas. 


\section{SECINĀJUMI}

1. Pacientiem ar multiplo sklerozi aferentajā redzes sistēmā vērojamas funkcionālas (redzes asuma, redzes izraisīto potenciālu amplitūdas un latences, krāsu redzes, redzes lauku) izmaiņas un strukturālas izmaiņas (temporāls redzes nerva diska nobālējums, tīklenes nervu šķiedru slāṇa samazinājums), kas nav saistītas ar iepriekšēju klīnisku redzes nerva iekaisuma epizodi.

2. Ar multiplo sklerozi slimajiem pacientiem neatkarīgi no klīniskas redzes nerva iekaisuma epizodes anamnēzē vērojama aferento redzes ceḷu strukturālu un funkcionālu izmaiņu savstarpēja korelācija.

3. Neirodeǵeneratīvas izmaiņas tīklenē korelē ar slimības ilgumu, invaliditātes pakāpi, redzes asumu (pacientiem bez redzes nerva neirīta anamnēzē), krāsu redzi, redzes laukiem, redzes nerva diska temporālu nobālējumu, redzes izraisīto potenciālu N 75/ P 100 amplitūdu, P 100 latenci, kā arī demielinizējošu perēkḷu skaitu un lokalizāciju galvas smadzenēs un galvas smadzeņu atrofiju.

4. Pagarināta redzes izraisīto potenciālu P 100 latence labāk nekā samazināta N 75/P 100 amplitūda un ar optisko koherences tomogrāfiju diagnosticēts samazināts tīklenes nervu šķiedru slāṇa biezums apstiprina klīnisku redzes nerva neirīta epizodi.

5. Strukturālu tīklenes nervu šķiedru slāṇa bojājumu iespējams prognozēt, izmantojot funkcionālu izmeklēšanas metodes - redzes izraisīto potenciālu N 75/ P 100 amplitūdas un P 100 latences mērījumus. 


\section{PRAKTISKĀS REKOMENDĀCIJAS}

N̦emot vērā iespējamās subklīniskās izmaiṇas redzes sistēmā, visiem pacientiem ar multiplo sklerozi vēlams veikt detalizētus redzes sistēmas funkcionālus un strukturālus izmeklējumus. Gadījumos, kad šajos izmeklējumos tiek konstatētas izmaiṇas, vēlams veikt šo izmaiņu monitorēšanu dinamikā, iegūstot informāciju par neirodeǵeneratīvu procesu turpmāku attīstību.

Nākotnē iespējams aferentās redzes sistēmas izmeklējumu rezultātus izmantot kā neirodeǵeneratīvu procesu bioloǵiskus marḳierus, iekḷaujot tos kā sekundāru iznākumu mērījumus neiroprotektīvu un imūnmodulējošu medikamentu pētījumos. 


\section{PUBLIKĀCIJAS UN ZIṆOJUMI PAR PĒTĪJUMA TĒMU}

\section{Publikācijas par darba tēmu:}

Pastare, D., Kire, I., Laganovska, G., Millers, A. Use of optical coherence tomography to monitor multiple sclerosis. A review. Neurologijos Seminarai, 2012. 16 (54): p. 301-310.

Pastare, D., Kire, I., Erts R., Laganovska, G., Millers, A. Evaluation of axonal optic nerve damage using visual evoked potentials and optical coherence tomography in patients with multiple sclerosis. Medicina (Kaunas), 2013. 49 (11): p. 474-478.

Pastare, D., Kire, I., Laganovska, G., Millers, A. Diagnostics of subclinical optic nerve damage by optical coherence tomography in multiple sclerosis patients. Riga Stradiņš University, Collection of Scientific Papers, 2014. p. 29-33.

Pastare, D., Kire, I., Laganovska, G., Millers, A. Functional and structural evaluation of afferent visual system in multiple sclerosis patients. Proceedings of the Latvian Academy of Sciences. Section B, Vol. 69 (2015), No. 5 (698), p. 20-30.

Pastare, D., Kire, I., Laganovska, G., Millers, A. Reduced retinal nerve fiber layer prediction for multiple sclerosis patients. Riga Stradiņš University, Collection of Scientific Papers, 2015. p. 60-66.

\section{Ziṇojumi starptautiskās konferencēs un kongresos:}

Kire, I., Laganovska, G., Pastare, D., Millers, A. Assesment of optic nerve axonal pathology in multiple sclerosis patients using optical coherence tomography. European Society of Ophthalmology, Copenhagen, Denmark, June 8-11, 2013 (stenda referāts). 
Pastare, D. Optical coherence tomography in multiple sclerosis. The $7^{\text {th }}$ Baltic Congress of Neurology, Tartu, Estonia, May 9-12, 2012 (mutisks ziņojums).

Pastare, D., Kire, I., Laganovska, G., Millers, A. Assesment of optic nerve axonal pathology in multiple sclerosis patients using optical coherence tomography. European Federation of Neurological Societies, Stocholm, Sweden, September 8-11, 2012 (stenda referāts).

Pastare, D. Optic nerve as multiple sclerosis model. II Baltic Conference on Multiple Sclerosis and Autoimmune disorders, September 24, 2015 (mutisks ziņojums).

\section{Ziņojumi Latvijas konferencēs un kongresos:}

Pastare, D., Ķire, I. Laganovska, G., Šepetiene, S., Millers, A. Redzes izsaukto potenciālu parametru izmainas pacientiem ar multiplo sklerozi. 2012. gada RSU Zinātniskā konference (stenda referāts).

Pastare, D., Kire, I., Laganovska, G., Millers, A. Redzes nerva aksonāla bojajjuma izvērtēšana, izmantojot optisko koherences tomogrāfiju pacientiem ar multiplo sklerozi. 2012. gada RSU Zinātniskā konference (stenda referāts).

Pastare, D., Ķire, I., Laganovska, G., Millers, A. Funkcionālu un strukturālu redzes nervu izmeklējumu korelācija multiplās sklerozes pacientiem. 2013. gada RSU Zinātniskā konference (stenda referāts).

Pastare, D., Ķire, I., Erts, R., Laganovska, G., Millers, A. Redzes nerva aksonāla bojājuma diagnostika, izmantojot VEP un OCT metodes multiplās sklerozes pacientiem. 2014. gada RSU Zinātniskā konference (stenda referāts). 


\section{IZMANTOTĀ LITERATŪRA}

1. Abalo-Lojo, J. M., Limeres, C. C., Gomez, M. A., Baleato-Gonzalez, S., CadarsoSuarez, C., Capeans-Tome, C. and Gonzalez, F. Retinal nerve fiber layer thickness, brain atrophy, and disability in multiple sclerosis patients. J Neuroophthalmol. 2014, 34(1), 23-28. doi: 10.1097/wno.0000000000000057

2. Albrecht, P., Frohlich, R., Hartung, H. P., Kieseier, B. C., and Methner, A. Optical coherence tomography measures axonal loss in multiple sclerosis independently of optic neuritis. J Neurol. 2007, 254(11), 1595-1596. doi: 10.1007/s00415-007-05383

3. Alshowaeir, D., Yiannikas, C., Garrick, R., Parratt, J., Barnett, M. H., Graham, S. L., and Klistorner, A. Latency of multifocal visual evoked potentials in nonoptic neuritis eyes of multiple sclerosis patients associated with optic radiation lesions. Invest Ophthalmol Vis Sci. 2014, 55(6), 3758-3764. doi: 10.1167/iovs.1414571

4. Balcer, L. J. Clinical practice. Optic neuritis. N Engl J Med. 2006, 354(12), 12731280. doi: 10.1056/NEJMcp053247

5. Balcer, L. J. and Frohman, E. M. Evaluating loss of visual function in multiple sclerosis as measured by low-contrast letter acuity. Neurology. 2010, 74 Suppl 3, S 16-23. doi: 10.1212/WNL.0b013e3181dbb664

6. Bermel, R. A. and Balcer, L. J. Optic neuritis and the evaluation of visual impairment in multiple sclerosis. Continuum (Minneap Minn). 2013, 19(4 Multiple Sclerosis), 1074-1086. doi: 10.1212/01.CON.0000433282.00221.7e

7. Bock, M., Brandt, A. U., Dorr, J., Kraft, H., Weinges-Evers, N., Gaede, G. et al. Patterns of retinal nerve fiber layer loss in multiple sclerosis patients with or without optic neuritis and glaucoma patients. Clin Neurol Neurosurg. 2010, 112(8), 647652. doi: 10.1016/j.clineuro.2010.04.014

8. Browne, P., Chandraratna, D., Angood, C., Tremlett, H., Baker, C., Taylor, B. V., and Thompson, A. J. Atlas of Multiple Sclerosis 2013: A growing global problem with widespread inequity. Neurology. 2014, 83(11), 1022-1024. doi: 10.1212/WNL.0000000000000768

9. Bruck, W. The pathology of multiple sclerosis is the result of focal inflammatory demyelination with axonal damage. J Neurol. 2005, 252, Suppl 5, v3-9. doi: 10.1007/s00415-005-5002-7

10. Chan, J. W. Recent advances in optic neuritis related to multiple sclerosis. Acta Ophthalmol. 2012, 90(3), 203-209. doi: 10.1111/j.1755-3768.2011.02145.x

11. Costello, F. The Afferent Visual Pathway: Designing a Structural-Functional Paradigm of Multiple Sclerosis. ISRN Neurology. 2013, 17. doi: $10.1155 / 2013 / 134858$

12. Costello, F., Coupland, S., Hodge, W., Lorello, G. R., Koroluk, J., Pan, Y. I. et al. Quantifying axonal loss after optic neuritis with optical coherence tomography. Ann Neurol. 2006, 59(6), 963-969. doi: 10.1002/ana.20851 
13. Costello, F., Hodge, W., Pan, Y. I., Eggenberger, E., Coupland, S., and Kardon, R. H. Tracking retinal nerve fiber layer loss after optic neuritis: a prospective study using optical coherence tomography. Mult Scler. 2008, 14(7), 893-905. doi: 10.1177/1352458508091367

14. Cruz Gomez, A. J., Ventura Campos, N., Belenguer, A., Avila, C., and Forn, C. Regional brain atrophy and functional connectivity changes related to fatigue in multiple sclerosis. PLoS One. 2013, 8(10), e77914. doi: 10.1371/journal.pone.0077914

15. Davies, E. C., Galetta, K. M., Sackel, D. J., Talman, L. S., Frohman, E. M., Calabresi, P. A. et al. Retinal ganglion cell layer volumetric assessment by spectraldomain optical coherence tomography in multiple sclerosis: application of a highprecision manual estimation technique. J Neuroophthalmol. 2011, 31(3), 260-264. doi: 10.1097/WNO.0b013e318221b434

16. Di Maggio, G., Santangelo, R., Guerrieri, S., Bianco, M., Ferrari, L., Medaglini, S., et al. Optical coherence tomography and visual evoked potentials: which is more sensitive in multiple sclerosis? Mult Scler. 2014. doi: 10.1177/1352458514524293

17. Fatehi, F., Shaygannejad, V., Mehr, L. K., and Dehghani, A. Optical coherence tomography versus visual evoked potential in multiple sclerosis patients. Iran $J$. Neurol. 2012, 11(1), 12-15.

18. Fernandez, O. Integrating the tools for an individualized prognosis in multiple sclerosis. J Neurol Sci. 2013, 331(1-2), 10-13. doi: 10.1016/j.jns.2013.04.021

19. Fisher, J. B., Jacobs, D. A., Markowitz, C. E., Galetta, S. L., Volpe, N. J., NanoSchiavi, M. L.et al. Relation of visual function to retinal nerve fiber layer thickness in multiple sclerosis. Ophthalmology. 2006, 113(2), 324-332. doi: 10.1016/j.ophtha.2005.10.040

20. Fisniku, L. K., Chard, D. T., Jackson, J. S., Anderson, V. M., Altmann, D. R., Miszkiel, K. A. et al. Gray matter atrophy is related to long-term disability in multiple sclerosis. Ann Neurol. 2008, 64(3), 247-254. doi: 10.1002/ana.21423

21. Fjeldstad, C., Bemben, M., and Pardo, G. Reduced retinal nerve fiber layer and macular thickness in patients with multiple sclerosis with no history of optic neuritis identified by the use of spectral domain high-definition optical coherence tomography. J Clin Neurosci. 2011, 18(11), 1469-1472. doi: 10.1016/j.jocn.2011.04.008

22. Frohman, E. M., Frohman, T. C., Zee, D. S., McColl, R. and Galetta, S. The neuroophthalmology of multiple sclerosis. Lancet Neurol. 2005, 4(2), 111-121. doi: 10.1016/s1474-4422(05)00992-0

23. Garcia-Martin, E., Pueyo, V., Martin, J., Almarcegui, C., Ara, J. R., Dolz, I. et al. Progressive changes in the retinal nerve fiber layer in patients with multiple sclerosis. Eur J Ophthalmol. 2010, 20(1), 167-173.

24. Gelfand, J. M., Goodin, D. S., Boscardin, W. J., Nolan, R., Cuneo, A. and Green, A. J. Retinal axonal loss begins early in the course of multiple sclerosis and is similar between progressive phenotypes. PLoS One. 2012, 7(5), e36847. doi: 10.1371/journal.pone.0036847

25. Gordon-Lipkin, E., Chodkowski, B., Reich, D. S., Smith, S. A., Pulicken, M., Balcer, L. J. et al. Retinal nerve fiber layer is associated with brain atrophy in 
multiple sclerosis. Neurology. 2007, 69(16), 1603-1609. doi: 10.1212/01.wnl.0000295995.46586.ae

26. Grazioli, E., Zivadinov, R., Weinstock-Guttman, B., Lincoff, N., Baier, M., Wong, J. R. et al. Retinal nerve fiber layer thickness is associated with brain MRI outcomes in multiple sclerosis. J Neurol Sci. 2008, 268(1-2), 12-17. doi: 10.1016/j.jns.2007.10.020

27. Herrero, R., Garcia-Martin, E., Almarcegui, C., Ara, J. R., Rodriguez-Mena, D., Martin, J. et al. Progressive degeneration of the retinal nerve fiber layer in patients with multiple sclerosis. Invest Ophthalmol Vis Sci. 2012, 53(13), 8344-8349. doi: 10.1167/iovs.12-10362

28. Holder, G. E., Celesia, G. G., Miyake, Y., Tobimatsu, S., and Weleber, R. G. International Federation of Clinical Neurophysiology: recommendations for visual system testing. Clin Neurophysiol. 2010, 121(9), 1393-1409. doi: 10.1016/j.clinph.2010.04.010

29. Hood, D. C., Salant, J. A., Arthur, S. N., Ritch, R. and Liebmann, J. M. The location of the inferior and superior temporal blood vessels and interindividual variability of the retinal nerve fiber layer thickness. J Glaucoma. 2010, 19(3), 158-166. doi: 10.1097/IJG.0b013e3181af31ec

30. Keltner, J. L., Johnson, C. A., Cello, K. E., Dontchev, M., Gal, R. L., and Beck, R. W. Visual field profile of optic neuritis: a final follow-up report from the optic neuritis treatment trial from baseline through 15 years. Arch Ophthalmol. 2010, 128(3), 330-337. doi: 10.1001/archophthalmol.2010.16

31. Klistorner, A., Arvind, H., Nguyen, T., Garrick, R., Paine, M., Graham, S. et al. Axonal loss and myelin in early $\mathrm{ON}$ loss in postacute optic neuritis. Ann Neurol. 2008, 64(3), 325-331. doi: 10.1002/ana.21474

32. Klistorner, A., Arvind, H., Nguyen, T., Garrick, R., Paine, M., Graham, S. et al. Multifocal VEP and OCT in optic neuritis: a topographical study of the structurefunction relationship. Doc Ophthalmol. 2009, 118(2), 129-137. doi: 10.1007/s10633-008-9147-4

33. Klistorner, A., Garrick, R., Barnett, M. H., Graham, S. L., Arvind, H., Sriram, P., and Yiannikas, C. Axonal loss in non-optic neuritis eyes of patients with multiple sclerosis linked to delayed visual evoked potential. Neurology. 2013, 80(3), 242245. doi: 10.1212/WNL.0b013e31827deb39

34. Kurtzke, J. F. Rating neurologic impairment in multiple sclerosis: an expanded disability status scale (EDSS). Neurology. 1983, 33(11), 1444-1452.

35. Martinez-Lapiscina, E. H., Ortiz-Perez, S., Fraga-Pumar, E., Martinez-Heras, E., Gabilondo, I., Llufriu, S. et al. Colour vision impairment is associated with disease severity in multiple sclerosis. Mult Scler. 2014, 20(9), 1207-1216. doi: $10.1177 / 1352458513517591$

36. McDonald, W., Compston, A., Edan, G., Goodkin, D., Hartung, H., Lublin, F. et al. Recommended diagnostic criteria for multiple sclerosis: guidelines from the International Panel on the Diagnosis of Multiple Sclerosis. Ann Neurol. 2001, 50, $121-127$. 
37. Merle, H., Olindo, S., Donnio, A., Beral, L., Richer, R., Smadja, D. and Cabre, P. Retinal nerve fiber layer thickness and spatial and temporal contrast sensitivity in multiple sclerosis. Eur J Ophthalmol. 2010, 20(1), 158-166.

38. Moghaddasi, M., Hosseini Nasab, A., Shirali, A., and Soltan Sanjari, M. Evaluation of relation between the retinal nerve fiber layer and Expanded Disability Status Scale (EDSS) in patients with relapsing-remitting form of multiple sclerosis referring to Rasool Akram Hospital. [Research]. Razi Journal of Medical Sciences. 2010, 18(87), 36-43.

39. Naismith, R. T., Tutlam, N. T., Xu, J., Shepherd, J. B., Klawiter, E. C., Song, S. K., and Cross, A. H. Optical coherence tomography is less sensitive than visual evoked potentials in optic neuritis. Neurology. 2009, 73(1), 46-52. doi: 10.1212/WNL.0b013e3181aaea32

40. Neuro-Ophthalmology Review Manual. $7^{\text {th }}$ ed. Thorofare, NJ, USA: SLACK Incorporated, 2012.

41. Oberwahrenbrock, T., Schippling, S., Ringelstein, M., Kaufhold, F., Zimmermann, H., Keser, N. et al. Retinal damage in multiple sclerosis disease subtypes measured by high-resolution optical coherence tomography. Mult Scler Int. 2012, 530305. doi: 10.1155/2012/530305

42. Odom, J. V., Bach, M., Brigell, M., Holder, G. E., McCulloch, D. L., Tormene, A. P., and Vaegan. ISCEV standard for clinical visual evoked potentials (2009 update). Doc Ophthalmol. 2010, 120(1), 111-119. doi: 10.1007/s10633-0099195-4

43. Outteryck, O., Zephir, H., Defoort, S., Bouyon, M., Debruyne, P., Bouacha, I. et al. Optical coherence tomography in clinically isolated syndrome: no evidence of subclinical retinal axonal loss. Arch Neurol. 2009, 66(11), 1373-1377. doi: 10.1001/archneurol.2009.265

44. Parisi, V., Manni, G., Spadaro, M., Colacino, G., Restuccia, R., Marchi, S. et al. Correlation between morphological and functional retinal impairment in multiple sclerosis patients. Invest Ophthalmol Vis Sci. 1999, 40(11), 2520-2527.

45. Petzold, A., de Boer, J. F., Schippling, S., Vermersch, P., Kardon, R., Green, A. et al. Optical coherence tomography in multiple sclerosis: a systematic review and meta-analysis. Lancet Neurol. 2010, 9(9), 921-932. doi: 10.1016/s14744422(10)70168-x

46. Polman, C. H., Reingold, S. C., Banwell, B., Clanet, M., Cohen, J. A., Filippi, M. et al. Diagnostic criteria for multiple sclerosis: 2010 Revisions to the McDonald criteria. Annals of Neurology. 2011, 69(2), 292-302. doi: 10.1002/ana.22366

47. Polman, C. H., Reingold, S. C., Edan, G., Filippi, M., Hartung, H. P., Kappos, L. et al. Diagnostic criteria for multiple sclerosis: 2005 revisions to the "McDonald Criteria”. Ann Neurol. 2005, 58(6), 840-846. doi: 10.1002/ana.20703

48. Popescu, V., Agosta, F., Hulst, H. E., Sluimer, I. C., Knol, D. L., Sormani, M. P. et al. Brain atrophy and lesion load predict long term disability in multiple sclerosis. $J$ Neurol Neurosurg Psychiatry. 2013, 84(10), 1082-1091. doi: 10.1136/jnnp-2012304094 
49. Pueyo, V., Martin, J., Fernandez, J., Almarcegui, C., Ara, J., Egea, C. et al. Axonal loss in the retinal nerve fiber layer in patients with multiple sclerosis. Mult Scler. 2008, 14(5), 609-614. doi: 10.1177/1352458507087326

50. Quelly, A., Cheng, H., Laron, M., Schiffman, J. S. and Tang, R. A. Comparison of optical coherence tomography and scanning laser polarimetry measurements in patients with multiple sclerosis. Optom Vis Sci. 2010, 87(8), 576-584. doi: 10.1097/OPX.0b013e3181e3dcb3

51. Sakai, R. E., Feller, D. J., Galetta, K. M., Galetta, S. L., and Balcer, L. J. Vision in multiple sclerosis: the story, structure-function correlations, and models for neuroprotection. $J$ Neuroophthalmol. 2011, 31(4), 362-373. doi: 10.1097/WNO.0b013e318238937f

52. Seigo, M. A., Sotirchos, E. S., Newsome, S., Babiarz, A., Eckstein, C., Ford, E. et al. In vivo assessment of retinal neuronal layers in multiple sclerosis with manual and automated optical coherence tomography segmentation techniques. $J$ Neurol. 2012, 259(10), 2119-2130. doi: 10.1007/s00415-012-6466-x

53. Sepulcre, J., Murie-Fernandez, M., Salinas-Alaman, A., Garcia-Layana, A., Bejarano, B., and Villoslada, P. Diagnostic accuracy of retinal abnormalities in predicting disease activity in MS. Neurology. 2007, 68(18), 1488-1494. doi: 10.1212/01.wnl.0000260612.51849.ed

54. Serbecic, N., Aboul-Enein, F., Beutelspacher, S. C., Graf, M., Kircher, K., Geitzenauer, W. et al. Heterogeneous pattern of retinal nerve fiber layer in multiple sclerosis. High resolution optical coherence tomography: potential and limitations. PLoS One. 2010, 5(11), e13877. doi: 10.1371/journal.pone.0013877

55. Siffrin, V., Vogt, J., Radbruch, H., Nitsch, R. and Zipp, F. Multiple sclerosis candidate mechanisms underlying CNS atrophy. Trends Neurosci. 2010, 33(4), 202-210. doi: 10.1016/j.tins.2010.01.002

56. Slotnick, S. D., Klein, S. A., Carney, T., Sutter, E., and Dastmalchi, S. Using multistimulus VEP source localization to obtain a retinotopic map of human primary visual cortex. Clin Neurophysiol. 1999, 110(10), 1793-1800.

57. Talman, L. S., Bisker, E. R., Sackel, D. J., Long, D. A., Jr., Galetta, K. M., Ratchford, J. N. et al. Longitudinal study of vision and retinal nerve fiber layer thickness in multiple sclerosis. Ann Neurol. 2010, 67(6), 749-760. doi: 10.1002/ana.22005

58. Tatrai, E., Simo, M., Iljicsov, A., Nemeth, J., Debuc, D. C., and Somfai, G. M. In vivo evaluation of retinal neurodegeneration in patients with multiple sclerosis. PLoS One. 2012, 7(1), e30922. doi: 10.1371/journal.pone.0030922

59. The clinical profile of optic neuritis. Experience of the Optic Neuritis Treatment Trial. Optic Neuritis Study Group. Arch Ophthalmol. 1991, 109(12), 1673-1678.

60. Toledo, J., Sepulcre, J., Salinas-Alaman, A., Garcia-Layana, A., MurieFernandez, M., Bejarano, B., and Villoslada, P. Retinal nerve fiber layer atrophy is associated with physical and cognitive disability in multiple sclerosis. Mult Scler. 2008, 14(7), 906-912. doi: 10.1177/1352458508090221

61. Trapp, B. D., Peterson, J., Ransohoff, R. M., Rudick, R., Mork, S., and Bo, L. (1998). Axonal transection in the lesions of multiple sclerosis. $N$ Engl J Med. 338(5), 278-285. doi: 10.1056/NEJM199801293380502 
62. Trip, S. A., Schlottmann, P. G., Jones, S. J., Altmann, D. R., Garway-Heath, D. F., Thompson, A. J., Miller, D. H. (2005). Retinal nerve fiber layer axonal loss and visual dysfunction in optic neuritis. Ann Neurol. 58(3), 383-391. doi: 10.1002/ana.20575

63. Urano, T., Matsuura, T., Yukawa, E., Arai, M., Hara, Y., and Yamakawa, R. Retinal nerve fiber layer thickness changes following optic neuritis caused by multiple sclerosis. Jpn J Ophthalmol. 2011, 55(1), 45-48. doi: 10.1007/s10384-010-0902-1

64. Villoslada, P., Cuneo, A., Gelfand, J., Hauser, S. L., and Green, A. Color vision is strongly associated with retinal thinning in multiple sclerosis. Mult Scler. 2012, 18(7), 991-999. doi: 10.1177/1352458511431972

65. Voss, E., Raab, P., Trebst, C., and Stangel, M. Clinical approach to optic neuritis: pitfalls, red flags and differential diagnosis. Ther Adv Neurol Disord. 2011, 4(2), 123-134. doi: 10.1177/1756285611398702

66. Walter, S. D., Ishikawa, H., Galetta, K. M., Sakai, R. E., Feller, D. J., Henderson, S. B. et al. Ganglion cell loss in relation to visual disability in multiple sclerosis. Ophthalmology. 2012, 119(6), 1250-1257. doi: 10.1016/j.ophtha.2011.11.032

67. Wang, X. L., Yu, T., Xia, D. Z., Zhang, J. S., Yan, Q. C., and Luo, Y. H. Measurement of retinal nerve fiber layer thickness in optic atrophy eyes of patients with optic neuritis using optical coherence tomography. Graefes Arch Clin Exp Ophthalmol. 2010, 248(7), 1013-1018. doi: 10.1007/s00417-010-1326-9

68. WHO. Atlas Multiple Sclerosis Resources in the World 2008. Albany, NY, USA: WHO, 2008.

69. You, Y., Klistorner, A., Thie, J., and Graham, S. L. Latency delay of visual evoked potential is a real measurement of demyelination in a rat model of optic neuritis. Invest Ophthalmol Vis Sci. 2011, 52(9), 6911-6918. doi: 10.1167/iovs.11-7434

70. Zaveri, M. S., Conger, A., Salter, A., Frohman, T. C., Galetta, S. L., Markowitz, C. E. et al. Retinal imaging by laser polarimetry and optical coherence tomography evidence of axonal degeneration in multiple sclerosis. Arch Neurol. 2008, 65(7), 924-928. doi: 10.1001/archneur.65.7.924

71. Zipp, F. and Aktas, O. The brain as a target of inflammation: common pathways link inflammatory and neurodegenerative diseases. Trends Neurosci. 2006, 29(9), 518-527. doi: 10.1016/j.tins.2006.07.006

72. Zivadinov, R., Bergsland, N., Cappellani, R., Hagemeier, J., Melia, R., Carl, E. et al. Retinal nerve fiber layer thickness and thalamus pathology in multiple sclerosis patients. Eur J Neurol. 2014, 21(8), 1137-e1161. doi: 10.1111/ene.12449 


\section{PATEICĪBAS}

Izsaku lielu pateicību darba vadītājam profesoram Andrejam Milleram par iedrošinājumu veikt pacientu ar multiplo sklerozi izpēti, kā arī par atbalstu un vērtīgiem ieteikumiem promocijas darba veidošanā.

Liels paldies profesorei Gunai Laganovskai par palīdzību, veicot redzes izmeklējumus, un iespēju strādāt Paula Stradiṇa Klīniskās universitātes slimnīcas Oftalmolog̣ijas klīnikā.

Izsaku pateicību Paula Stradiṇa Klīniskās universitātes slimnīcas Oftalmoloǵijas klīnikas ārstei Ievai Ķirei par nesavtīgu palīdzību redzes izmeklējumu veikšanā, kā arī oftalmologam Svetlanai Šepetienei par vērtīgiem padomiem, veicot redzes izraisīto potenciālu izmeklējumus.

Pateicos docentam Renāram Ertam par palīdzību un konsultācijām, veicot statistikas aprēḳinus.

Sirsnīgs paldies visam Paula Stradiņa Klīniskās universitātes slimnīcas Neiroloğijas klīnikas kolektīvam, īpaši profesorei Inārai Loginai, profesorei Evijai Miglānei un docentei Viktorijai K̦ēniņai par palīdzību, morālo atbalstu, sapratni un iedrošinājumu.

Liels paldies Paula Stradiņa Klīniskās universitātes slimnīcas Diagnostiskās radiolog̣ijas institūta radiologiem Sarmītei Dzelzìtei un Jolantai Rozentālei par palīdzību magnētiskās rezonanes izmeklējumu protokola veidošanā un rezultātu interpretācijā.

Vislielākais paldies manai mịlajai ǵimenei - vīram, bērniem un vecākiem par palīdzību, iecietību, sapratni un neatsveramo atbalstu promocijas darba tapšanas laikā. 